Article

\title{
The "Smart Village" as a Way to Achieve Sustainable Development in Rural Areas of Poland
}

\author{
Mieczysław Adamowicz *(D) and Magdalena Zwolińska-Ligaj \\ Pope John Paul II State School of Higher Education in Biala Podlaska, Faculty of Economic Sciences, \\ Sidorska 95/97 str., 21-500 Biała Podlaska, Poland; m.zwolinska-ligaj@dydaktyka.pswbp.pl \\ * Correspondence: adamowicz.mieczyslaw@gmail.com
}

Received: 27 June 2020; Accepted: 29 July 2020; Published: 12 August 2020

check for updates

\begin{abstract}
In each country, rural areas cover the bulk of available land; however, they generally remain outside the mainstream of innovative development processes. Still, they have potential and are vital for implementing the highly valid concept of persistent and sustainable development. The idea of such growth can be implemented in many ways, and the smart development concept is one of these ways. The aim of this paper is to present the smart village concept as a means to achieve the sustainability and resilience of rural areas, relying on the analysis of basic theories of sustainable and persistent growth. The study examines and evaluates the state of the potential for the smart growth of rural areas in all regions of Poland, as well as presents the results of the empirical research on such potential in three regions of Eastern Poland. The smart growth potential of the regions in question was determined by means of 24 variables representing the following fields: management, life quality, economy, society, natural environment and mobility. It was concluded that the smart village concept can be useful in facilitating sustainable development of rural areas. Further research concerning the problem should in particular focus on strengthening the relations between rural communes with cities and towns in their close vicinity.
\end{abstract}

Keywords: rural areas; sustainable development; smart development; smart village; development factors; Lubelskie voivodeship

\section{Introduction}

During the last forty years, Poland has fundamentally transformed from a society functioning under the conditions of a socialist regime and a centrally planned economy into a democracy and market economy. In 2004, Poland became a member of the European Union. Through the phenomenon of convergency, the country is catching up fast with other, more developed, European countries. Changes concerning the system, the society and the economy have also affected agriculture and rural areas, which to a large extent have kept their nation- and region-specific development characteristics.

Rural areas cover around $93 \%$ of the country, being the home for nearly $40 \%$ of the population [1]. In the second half of the 20th century, they evolved from places dominated by agriculture and other natural sectors (such as forestry, hunting and fishing) into residential areas for the non-agricultural parts of society, as well as the places of activity for some other non-agricultural production and service economy sectors. Despite significant progress and development, their economic and social infrastructure is still less developed than that of urban areas. They also cannot compete with towns and cities in terms of the level of income and the quality of living conditions they provide. Rural areas are also places where various problems and forms of social pathology occur more often. On the other hand, they perform some other vital roles concerning the whole economy and society more widely than other areas. By becoming multifunctional areas, they deliver goods and services that benefit the public. 
Rural areas should speed up their growth in order to limit their developmental disparities and make a contribution to the general socio-economic progress of the country. Their natural, endogenous growth potential might be reinforced by restructuring and revivification processes, through establishing improved policies and the implementation of local development strategies. The experiences of many countries show that innovations should play the key role in such programs. These innovations, both technological and social, could be used for boosting the potential for sustainable and permanent growth of rural areas. The adoption of innovative concepts of the smart development of agriculture and non-agricultural sectors of rural economy, including the shaping of modern "smart villages" as well as the corresponding "smart specialization" of production, can be one of the ways of providing such support for rural areas. In order to implement such solutions, it is necessary to establish local innovation systems aimed at reinforcing and widening the sustainable and permanent form of rural and urban-rural communes' growth and development.

These newly emerging features of rural areas, as well as meeting the need for new methods for increasing rural sustainability, require both broadening the existing knowledge and selecting new, more efficient methods of development implementation. While the process of growth and development of rural areas can be observed in Poland, the gap becomes increasingly visible in research. Such studies could create a knowledge base and propose a set of tools supporting the strategies, policies and activities for achieving sustainable rural development on both regional and local levels.

This paper mainly aims at investigating the possibility of the "smart village" development concept as a suitable way to address sustainability in rural development. The study is based on two types of findings: first, it presents the subject's literature review as a theoretical basis for links between the concept of the "smart village" and sustainable rural development; further, it reveals the results of empirical research concerning factors that shape the potential of regions and rural communities for "smart village" concept implementation in selected local systems in regions of Eastern Poland recognized as the peripheral ones.

\section{Theoretical Background}

\subsection{The Substance and Factors of the Sustainable Development of Rural Areas}

The concept of sustainable development can be defined as the use of a set of actions aimed at satisfying the basic needs of a given population or community while preserving natural resources for future generations [2]. This is one of many definitions that followed the very first definition formulated in the Brundtland Report for the World Commission on Environment and Development, where sustainable development was originally defined as development that "meets the needs of the present without compromising future generations to meet their own needs" [3]. The core concept of sustainable development and sustainability "is [often] contested as a chaotic concept, accused of meaning of everything and nothing, and used to justify almost anything", mainly due to its ambiguity [4]. The ambiguity of its definitions, its integrative character and its holistic nature have facilitated the acceptance of the idea of sustainability in different scientific disciplines, sectors of the economy and society, as well as across ideological national and cultural divides [5]. The meaning and essence of sustainability have been analyzed and assessed from different perspectives, ever since the concept was brought up on the political and social agenda. The original meaning of sustainability was strongly related to the need for the protection of environmental resources, but later it acquired the sense of including endless, neo-liberal, durable development based on economic growth with some limits to exploitation of natural resources. Finally, social sustainability was added as the third dimension of the concept [6].

The idea originated in the need to stop the degradation of the natural environment, and very soon was transferred onto social and economic aspects of development. For the last fifty years, it has been receiving contributions from various scientific disciplines, and therefore has become the basic underlying paradigm of all programs, policies and development strategies formulated by international 
organizations, governments and local authorities. Ensuring the permanent improvement of the quality of life for present and future generations by shaping the rational proportions between different types of capital, such as economic, human, social or natural, still remains the core of the concept [7].

Nowadays, the term "sustainable development" is used by scientists, business activists, and politicians. For this reason, two different processes may be observed. The first trend extends the scope of sustainability beyond environmental, economic and social dimension, e.g., for institutional or ethic areas. The other one strives towards intensifying and strengthening the connections inside the "boundary term", where science meets practitioners and politicians. The idea of "sustainable livelihoods" is an example of such process [7,8]. "A livelihood comprises the capabilities, material and social assets and activities required for a means of living. A livelihood is sustainable when it copes with and recovers from stresses and shocks and maintains or enhances its capabilities and assets both now and in the future, while not undermining the natural resource base" [6].

Currently, together with "sustainability", the "persistence" element is more and more often accentuated within the concept of sustainable development. Such persistence means the functioning of the economy and the society (also various sectors of economy such as agriculture and forestry) aimed at the pursuit of current economic benefits while saving the entire development potential for future generations. On the other hand, sustainability means maintaining current and future balance between economic, social, and environmental aspect of development, taking into account rational structures and means of existence for the economy and the society in a human-friendly environment.

In particular, the concept of sustainable development refers to rural areas, definitely covering the bulk of Poland's surface, as well as to natural sectors of the economy, such as agriculture, forestry, fishing, and mining located in those areas. For a long time, rural areas were perceived as an agro-food production area, which caused rural development to be understood as nearly synonymous to agricultural development. The concept of rural development in Europe changed during the post-war period. T. Marsden explores three models of rural development dynamics: the agro-industrial model, the post-productivist model, and the emerging, sustainable rural development model, in which rural sustainability is growing in importance [9].

The first model dominated the European countryside until the end of the 1980s. Post-productivist dynamics appeared mainly in the last decade of the twentieth century. According to this approach, rural areas are treated as a space of consumption, not only space for agricultural development. It enhanced industrialized agricultural production in many rural areas in west and north European countries, mainly in rich, urbanized regions surrounding big cities. The sustainable rural development model represents integrated activity in economic, social and environmental fields. Its role was strengthened as a result of the Agenda 2000 CAP policy reform - the model received support from the second pillar of the CAP and was aided under some other European funds and policies. The three models appeared consecutively during the post-war period; however, all of them have been co-evolving and competing at the same time until now. The models are dynamic and characterized by a different level of real sustainability. All are partly unsustainable, and partly sustainable; all have some barriers and opportunities for rural development. Each of them represents a different mix of market, state and social participation, and requires particular types of political and economic actions for enhancing the potential for sustainable development of rural areas.

For twenty years, sustainability has become the basic paradigm of rural development programs, policies and strategies formulated by economic and social scientists, international organizations, national governments and local or regional government bodies. Its essence still remains unchanged: to ensure the permanent improvement in the quality of life of contemporary and future generations by establishing rational proportions between various types of capital-economic, social and natural capital [10]. This means that the idea announced in 1987 by the United Nations, stating that the growth of rural areas meant striving towards the improvement of living conditions and managing economy without the violation of specific rural resources, such as natural habitats, landscape and cultural heritage, is still valid. Such attitude attempts to reconcile natural, economic and social laws [11]. 
Ch. Bryant and D. Granjon [12] define "rural sustainability as a continuous search for development strategies (aimed at general improvement in human conditions) to maintain and produce "healthy" rural communities in which economic, socio-cultural, political and environmental values are compatible and which respond to any imperatives in these dimensions, at least in the long run". They claim that the issue of rural sustainability is similar to the urban one. However, differences can be traced in the type of environment, population density, and the conditions of economic activity. Such dissimilarities also refer to the emerging developmental problems and suggested solutions.

The need for sustainable development is raised in papers and strategies of the United Nations (Agenda 21) and its specialized institutions such as the Food and Agriculture Organization (FAO), the Organization for Economic Cooperation and Development, the Council of Europe, treaties regulating the functioning of the European Union (The Maastricht Treaty, The Treaty of Amsterdam), and strategies formulated on their basis, such as the Lisbon Strategy, Europe 2020, and others [13-16]. In 2015, more than 190 countries acting within the framework of the United Nations pledged to meet 17 sustainable development goals (SDGs) to ensure global economic and social development, preserve the environment and consolidate peace [17]. Rural sustainability and the smartness of rural development is inevitably an important part of this activity, aimed at supporting the abovementioned goals. Table 1 shows a list of 17 SDGs for solving the present complex social, political, economic and environmental challenges for citizens, businesses, institutions, and governments [18].

Table 1. Seventeen sustainable development goals of the UN $[17,18]$.

\begin{tabular}{|c|c|c|c|c|c|}
\hline $\begin{array}{c}17 \text { Sustainable } \\
\text { development goals }\end{array}$ & 1. No poverty & 2. Zero hunger & $\begin{array}{l}\text { 3. Good health } \\
\text { and well-being }\end{array}$ & 4. Quality education & 5. Gender equality \\
\hline $\begin{array}{l}\text { 6. Clean water } \\
\text { and sanitation }\end{array}$ & $\begin{array}{c}\text { 7. Affordable } \\
\text { and clean energy }\end{array}$ & $\begin{array}{l}\text { 8. Decent work } \\
\text { and economic growth }\end{array}$ & $\begin{array}{l}\text { 9. Industry innovation, } \\
\text { and infrastructure }\end{array}$ & 10. Reduce inequalities & $\begin{array}{l}\text { 11. Sustainable cities } \\
\text { and communities }\end{array}$ \\
\hline $\begin{array}{l}\text { 12. Responsible } \\
\text { consumption } \\
\text { and production }\end{array}$ & 13. Climate action & 14. Life below water & 15. Life on land & $\begin{array}{l}\text { 16. Peace, justice } \\
\text { and strong institutions }\end{array}$ & 17. Partnerships for goals \\
\hline
\end{tabular}

The issue of the sustainable development of rural areas was raised in many different programs and strategies announced in the European Union by the European Parliament, the European Commission and specialized study or experts' groups [13-16]. The strategy of the sustainable development of the European Union, issued in 2001 and 2006, concentrated mainly on actions preventing climate change, and pointed out the need of environmental protection, care for sustainable production, public health and social exclusion prevention, as well as solving various demographic problems [19]. Taking into account rural areas, the most important documents are Cork Declarations (1.0 from 1996, and 2.0 from 2016), in which member countries adopted the program implementing the concept of sustainability in rural areas and set key directions of development for future years. Agenda 2030, issued by the UN in 2020, also underlines the mechanisms that should be developed in order to ensure sustainable growth of rural areas at the international, country, regional, and local level. Taking into account the significant diversification of rural areas, the set of 17 sustainable growth aims for such areas and 169 specific tasks must be adjusted to the geographical diversity and to the regional/local conditions which should enable combating poverty, climate change, environmental pollution, ensuring common safety and justice, etc. [18,20]. It is also stated that in addition to being food providers, rural areas are the reservoir of work resources used also in urban areas, a shelter for endangered plants and animals, as well as natural landscapes and areas in need of protection. Villages are an important element of the national and regional cultural heritage. Consequently, the sustainable growth of rural areas is a complex compilation of issues important for the entire population of a country. Area supplies management, together with setting the optimal proportions and balance between agricultural, built-up and communication areas, and those constituting natural resources, is the key issue for the development of rural areas. Agenda 2030 and the Paris Agreement can be classified as one of the most ambitious international initiatives concerning future economic development combined with environmental aspects. Figure 1 presents the multiplicity of rural development issues, emerging 
social challenges and environmental threats, the suggested approach to their systemic solutions, as well as the synergistic effects that should be achieved at different levels to shape and attain global development goals.

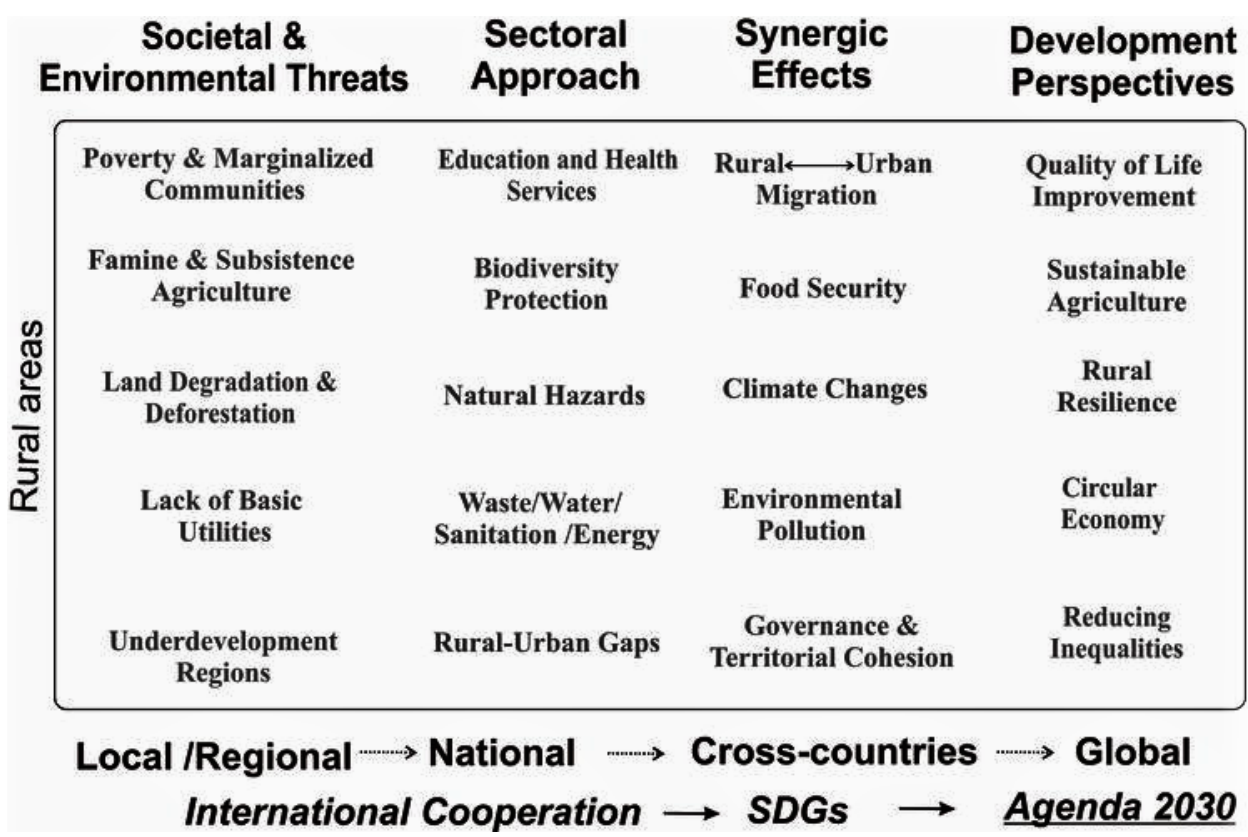

Figure 1. Challenges of rural communities under the Agenda 2030 framework [20].

While aiming at overcoming social, economic, and environmental threats occurring in rural areas, such as poverty, social marginalization, economic underdevelopment, environmental degradation, a lack of basic infrastructure and a lower level of economic viability of the resources used, long-term development goals have been defined. They include the improvement of living standards, development of sustainable agriculture, increasing resistance to unexpected events and threats, development of circular economy, reducing social inequalities, and building the local growth capability. Considering the diversity and complexity of the issue in question, we must take into consideration the relations between the current state and the level of development, problems waiting to be solved, the specific values of a given system, and achievable goals. Lekić, Gadžić and Milanović pinpoint the variety of both - the advantages of rural areas, and problems to be solved [21]. A summary of positive values and economic, social and environmental problems is shown in Table 2.

Table 2. Specific characteristics of rural areas [21].

\begin{tabular}{|c|c|c|}
\hline Rural Issues & Positive Values & Problems \\
\hline Economic & $\begin{array}{c}\text { Tourism } \\
\text { Farming } \\
\text { Interregional trade }\end{array}$ & $\begin{array}{c}\text { Agricultural problems } \\
\text { Lack of job opportunities } \\
\text { Lack of access to technology } \\
\text { Low level of services provided }\end{array}$ \\
\hline Social care & $\begin{array}{c}\text { Safety } \\
\text { Solidarity } \\
\text { Low population density } \\
\text { Tradition interaction } \\
\text { Joint family } \\
\text { Religious faith } \\
\text { Transfer of knowledge from generation to generation }\end{array}$ & $\begin{array}{c}\text { Poverty, isolation } \\
\text { Migration, stratification } \\
\text { Conservatism, limited mobility } \\
\text { Outflow of young-inflow of older adults } \\
\text { Lack of high-quality services } \\
\text { Lack of education options, gender gap } \\
\text { Poor quality of housing, lack of healthcare services } \\
\text { Lack of recreation and leisure opportunities }\end{array}$ \\
\hline Environmental & $\begin{array}{l}\text { Landscape } \\
\text { Natural environment }\end{array}$ & $\begin{array}{l}\text { Pollution (air, land, water) } \\
\text { Landscape degradation } \\
\text { Inappropriate land use } \\
\text { Underdeveloped infrastructure }\end{array}$ \\
\hline
\end{tabular}


Bański presents a very similar set of values for rural areas. He enumerates features such as open landscape, low population density, prevalence of an agriculture- and forest-dependent population, traditional, close-to-nature way of life and customs, extensive use of land (mainly agricultural and forest), scattered settlement, and the feeling of living in the country [22]. Specific characteristics of the conditions and development problems of rural areas are reflected in the formulation of the rural development growth categories [23].

To date, empirical research on sustainable growth indicates a large number of factors affecting the successful implementation of the concept of sustainable development of rural areas. It seems rational to apply the systemic approach, aiming at dealing in parallel with interrelated actions deriving from different spheres of economic and social life. A.A. Akgun et al. [24] as well as A. Czudec et al. [2] distinguished several groups of factors determining the sustainable growth of rural areas, which may be summarized as follows:

1. Social factors. The group includes factors such as eagerness to take common actions, tolerance and ability to establish and strengthen social relations, etc. The factors from this group determine the ability to break boundaries and isolation in the local system and use local specifics and local resources to trigger development processes. In practice, their use means building social capital.

2. Economic factors. These are: entrepreneurship, boosting economic viability, the differentiation of the structure of rural economy, building human capital, openness to external cooperation, promotional activity. A better use of economic factors enhances the competitiveness of a given area's system, boosts income and improves the general living conditions of the inhabitants.

3. Specific natural and cultural values of the local system. They result from the condition of the natural environment, geographical location, and the state of cultural resources representing the particular values and local attractions.

4. Factors stimulating innovativeness and its absorption. These are mainly concerned with the creation and use of internal innovations-product-related, technological, organizational or social, as well as the absorption of external innovations which cannot be produced on-site. The implementation of new production technologies in agriculture, providing both renewable energy, and new forms of bio-economy, the development of the new, non-agricultural forms of activity (agri-tourism, services, bioenergy, specific regional products, cultural events etc.) can serve as an example. The development of a network of connections with the use of ICT is a new form in this field.

5. Infrastructural factors. These include elements of technical, economic, organizational and social infrastructure. Such factors facilitate running local production processes, the functioning of the local society and the improvement of living conditions. They can also constitute an offer targeted at external stakeholders for public use of the rural area.

Successful implementation of the sustainable development concept requires focus on all groups of factors in a given system. Depending on specific features of a system, some factors might acquire special meaning. Strengthening inner innovativeness is particularly important, independent of the rural area's local specifics. The issue of innovation is the primary subject of this paper.

\subsection{Smart Growth as the Idea of Persistence and Sustainability of Rural Areas}

Although the concept of sustainable development has been adopted as the basis for development processes in rural areas, in practice the implementation of sustainable development encounters many barriers that are difficult to overcome [25]. However, even though the idea is in theory very catchy and desirable, it still remains more like a postulate and a wish [26]. Therefore, multiple and repeated attempts at executing, detailing and fully or partially implementing the concept should come as no surprise. There are many other approaches to the sustainable development of rural areas, all of which originate from the idea of the sustainable growth itself or are interrelated. These are: the concept of social, economic and spatial order, regeneration, eco-development, animation and development of local 
communities, building the capital of integrated local growth, countryside resilience, inclusive growth, and other [13,23-32]. The smart growth of rural areas is one of the newer concepts. While relying on the rules of stable and sustainable development, it responds to the need for building rural competitiveness based on the use of knowledge and innovativeness understood in a broader sense. Such an idea has become an attempt to merge two as if opposite development goals: sustainable and stable growth with competitiveness [33]. The innovativeness of territorial systems is also one of its features.

The origin of the smart development idea in reference to territorial systems should be traced back to various theories and concepts of socio-economic and territorial growth: the cluster theory, territorial competitiveness, the innovations theory, human capital, social capital, territorial embeddedness theory, innovation and production systems, innovative environment, learning regions, clusters, regional innovations systems, etc. [34]. All of the above-mentioned concepts were used in the formulation of regional development policies. Since the mid-1980s, they have been directed towards mobilizing the endogenous potential of the regions, enhancing interregional cooperation and innovativeness, especially in the EU countries. Refocusing the EU's regional policy towards its territorial orientation, with the crucial role of innovation, is explicit in the Lisbon Strategy set up in 2000. After its unsuccessful implementation it was transformed in 2010 into the new strategy "Europe 2020: A strategy for smart, sustainable and inclusive growth", which set development goals for Europe 2010-2020 [19]. The strategy "Europe 2020" indicated three interrelated priorities: smart, sustainable and inclusive growth. The document also established the parameters and criteria referring to the development of agriculture and rural areas [13].

Smart development included striving for strengthening the economy based on knowledge and innovation through reinforcing European innovative potential, the outcomes of education processes, improving the quality and outcomes of educational institutions, and making use of the digital society's economic and social possibilities. The "Innovation Union" was one of the key elements for the implementation of the strategy. The initiative defined smart specializations as the tool for enhancing regional competitiveness. Regional Innovation Strategies for Smart Specialization (RIS3) after 2010 set the priorities in regional development in order to gain competitive advantage through the development of the assets of areas by means of research, innovative potential and economic needs, for creating a coherent development program while maintaining economical use of available resources [35].

In the EU countries, the concept of smart specializations was used for supporting innovation and innovativeness, both in urban and rural areas, as well as sectors, including agriculture. The idea is based on the assumption that neither the EU countries nor any other regions can achieve satisfactory results in all economic fields on their own, especially in new technologies and innovations [36]. Smart specializations also create development possibilities for the less developed regions, as they enable focusing on the development of the selected areas, where existing potential is meant to be used in full, as well as concentrate on specific domains in order to coordinate the use of specific and unique areas of competence in a region $[37,38]$.

In view of the implementation of "Europa 2020", the "smart village" concept appeared [39]. This idea refers to such rural areas and local (regional) communities that intend to base their development on their own strengths and resources. In a smart village, traditional and new networks and services are strengthened by means of digital technologies, ICT innovations and a better use of knowledge, with benefit to the residents and entrepreneurs. It can be expected that this idea will be playing more and more important role in the execution of rural areas' development programs in the EU countries after 2020 [40-42]. The concept of a smart village in the European Union is implemented within the European Network for Rural Development (ENRD), established in 2008 [28].

The concept of a "smart village", recognized as an important way to achieve rural sustainability, is rooted in two other concepts which had emerged earlier: "smart cities" and "bottom-up development" theories. The concept of "smart cities" is oriented towards saving resources, appropriate spatial 
planning, transport management, the reduction of costs resulting from urban sprawl, and extensive use of innovations related mainly to technology and digitalization. The use of information and digital technologies to create interactivity and efficiency of urban settlement, new investment in human and social capital, communication infrastructure, efficient use of resources, as well as extending participation of citizens in development programs were required. The idea of bottom-up development of local systems in rural areas may create village smartness by the extensive use of locally specific assets, including the tacit knowledge of communities affected by development pressure. The elements of the smart city model such as the environment, people, quality of life, management, mobility, economy, research and innovation, have quickly been transferred to the sphere of regional development, and recently, also to the rural sustainable development programming. The European Union Smart Village Programme aims at bridging these two original concepts [39].

The smart dimension of rural development still has not been precisely defined, and its implementation in practice may manifest itself in several forms. The smart element might also be integrated with other concepts that implement the Sustainable Development Goals addressed to rural communities, such as "knowledge-based economy", "circular economy", "bio-based economy", "rural resilience" and others $[27,28,43,44]$. The smart village concept refers to rural areas and rural communities that have built their development strategy on their existing assets and strengths, as well as by pursuing some new opportunities related to new digital technologies, networks and services that support better use of knowledge and innovative solutions for citizens, business and society. Smart villages "use innovative solutions to improve their resilience, building on local strengths and opportunities." [45]. One of the solutions which are based on local environments and the use of local/regional resources in line with designing the so-called smart development solutions is the LEADER approach, launched in 1991, and extended mainly after the accession of ten new members to the EU in 2004 [28]. LEADER was successfully implemented in most of the EU member states in the period of 2007-2013, as one of the four axes of the Rural Development Program [31,46]. In the programming period of 2014-2020, approximately 2600 Local Action Groups (LAGs) have been implementing the LEADER approach [28].

The LEADER initiative is based on the bottom-up local economic development model for rural areas also called the Community-Led Rural Development Theory. The functioning of LAGs under the LEADER Programme can be identified as a model example of cooperation, the essence of which is to manage the use of the local potential of human resources (human, social, relational capital). The cooperation is aimed at identifying and mobilizing the use (by definition, in an innovative way) of resources in local development processes. The neo-endogenous development mechanism can be initiated by LAGs starting to use the internal resources and external financial support from the EU [47]. Projects implemented under the LEADER initiative largely affect the formation of social capital. The LEADER philosophy is included in seven principles, namely: area-based local development strategies, bottom-up elaboration and implementation of strategies, local public-private partnerships, integrated and multi-sectoral actions, innovation, cooperation, and networking [48,49].

The idea of "smart villages" is consistent with the goals and recommendations listed in the 1996 Cork Declaration 1.0 ("A living countryside") and 2016 Cork Declaration 2.0 ("A better life in rural areas"). Cork 1.0, while identifying the priorities such as socio-economic diversification of the countryside and growth sustainability, pointed out several postulates concerning the development of business services, adequate infrastructure, education, training, information technology, support for small towns as the integral part of rural areas, as well as strengthening the resilience of rural communities and countryside regeneration. The document put an emphasis on preserving the quality of rural landscape, biological multifariousness and cultural identity. The vision of the countryside described in the second declaration by Cork (Cork 2.0) accentuated the existing differences between urban and rural areas, mainly in the field of digitalization, transport, communication, general interest and social services. The EU Action for Smart Village was launched by the European Commission in 2017. It was linked with the Common Agricultural Policy, Rural Development Policy, Cohesion Policy, 
and with some other programs such as Innovation Partnership for Agriculture, European Network for Rural Development. In 2018, the Bled Declaration was accepted. The document proposed some actions to improve conditions for developing smart farming and new services addressed mainly to rural youth [50]. In 2018, The Smart Village Network was also established.

The smart village concept assumes that social animation and technological progress, if successfully integrated with other rural development initiatives, can create new possibilities to increase income, improve the service offer and lead to strengthening local community in general, which in turn results in the improvement of life quality. When it comes to production, a smart village might mean investment in infrastructure, skillful management, implementing new technologies and smart specializations fitted in with the local conditions of production and selling markets. According to M. Wójcik [41], the most important areas for the smart village development are:

- Public services that satisfy the residents' needs, such as education, healthcare, safety, housing, etc.;

- Commune area management and co-management, including social participation in taking actions and decisions concerning their co-financing;

- Local communities' creativity, especially in seeking innovative solutions for coping with appearing social and economic problems;

- Technological innovation concerning the improvement of social cooperation and the growth of entrepreneurship;

- The development of communication, particularly modern means of communication, including Internet networks;

- Environmental protection and the development of new forms of engaging nature's potential for the society, including the increasing importance of alternative sources of energy.

As stated earlier, the "smart village" concept stresses the role of bottom-up activities facilitating development, performed by the local leaders in cooperation with the local government authorities, as well as the need to boost the transition of innovations to rural areas with a significant share of social innovations. Being the trigger of positive changes in the field of human and social capital, social innovations may enhance successful implementation of technological innovations. Adopting the idea of smart local development should contribute to and manifest itself in the creation of local innovation systems, developing under cooperative networks of businesses operating in various industries, and other economic and social agents [40,42]. The process of formation and interrelations within local innovation systems goes through several stages. Smart village, approached through the territorial dimension, means an area activating resources and capitals, including the relational capital, which develops by combining internal potential with external determiners of development, with emphasis on creating endogenous potential based not only on modern communication technologies, but also human capital and social potential, which build the development-enhancing partnerships with urban areas [25,40,43].

\section{Empirical Investigation}

\subsection{The Potential For the Smart Growth of Rural Areas in Poland}

So far, the knowledge and skills necessary for formulating the program and adopting the smart village concepts have not been well established. The implementation of theoretical assumptions of the concept itself by shaping them into a coherent research or implementation program is one of the difficulties. Conducting studies on smart growth potential in reference to rural areas is justified not only by the need to formulate plans and strategies for the development of local systems but also to underline the role of rural local systems in shaping regional and national policy. In Poland, there have been several attempts to design the tools for measuring the potential for rural areas' smart growth, first in rural and urban-rural communes of Lubelskie voivodeship, which was later spread across other voivodeships [40]. The research carried out with the use of this method helped in [23]: 
- Defining the state and the specific nature of structures of rural areas' smart growth potential from the regional point of view;

- Defining the status and the specific nature of structures of rural areas' smart growth potential from the local point of view-investigated rural and urban-rural communes in the regions;

- Creating the spatial characteristics of smart growth potential within the regions in questions.

Rural areas are defined as the land beyond the administrative borders of urban areas, which include rural and some urban-rural communes. The share of rural areas in each region is diversified (varying from $69.3 \%$ in Ślaskie to $97.5 \%$ in Warmińsko-Mazurskie). In 2018, there were 1548 rural communes and 628 urban-rural communes in Poland. Small communes, with a population below 5000 residents, are the most numerous (37.2\%). A total of 52,500 villages were registered within commune areas. On average, there were 292 people in a village, i.e., 10 people more than in 2010. It means that rural areas, apart from two voivodeships, are not being depopulated, and that the average population density has risen from 52 to 53 people per $\mathrm{km}^{2}$ for the last eight years. Poland is highly diversified in terms of population density. In 2018, there were 123 people per $\mathrm{km}^{2}$. The most densely populated areas, located in the south (Małopolskie), north-east (Podlaskie) and north-west (Zachodniopomorskie), have the lowest density rates. Five regions located in Eastern Poland (Warmińsko-Mazurskie, Podlaskie, Lubelskie, Podkarpackie and Świetokrzyskie) are recognized as peripheral, predominantly rural and least developed regions in Poland and in the European Union. Due to relative demographic stability, rural areas were inhabited by 15.3 million people in Poland in 2018, which was $39.9 \%$ of the country's population. The birth rate of the population in the majority of rural areas is still negative, the employment rate is slightly higher than in towns and cities (the mean for Poland is $53.8 \%$ ). In any case, the unemployment rate is lower. Only $4.2 \%$ working people in the countryside in 2018 declared agricultural activity. A total of $44.7 \%$ were employed in industry and construction in rural areas $(31.3 \%$ in urban areas). Employees of trade, car servicing, transport, warehouse management, accommodation, catering, and information and communication sectors together make $23.4 \%$ of the workforce $(25.7 \%$ in cities). A total of $27.7 \%$ are employed in the remaining services ( $42.7 \%$ in cities). The data show that agriculture is a shrinking sector of the rural economy, according to both employment criterion and contribution to the generated added value. The share of agriculture in land management is also diminishing. Agriculture, forestry, hunting and fishing in the years $2010-2018$ generated $2.1-2.9 \%$ of the GDP [1].

According to The Central Statistical Office (2020), in 2018 there were 1.4 million farms in Poland, of which small farms (approx. 1-5 ha) constituted the most numerous group. Farms from 5 to 30 ha cover over $40 \%$ of the utilized agricultural area. At the end of 2018, there were 4.4 million economic operators registered in the National Business Registry Number database, of which 1.2 million $(28.2 \%)$ were in rural areas. The number of economic agents operating in rural areas is growing fast. There were 80 operators per 1000 rural area residents, while in urban areas the number was 136 . The fast growth of non-agricultural economic agents in rural areas indicates the development of non-agricultural functions in the countryside and broadening multi-functionality of agriculture itself. The dynamic development of rural areas economic functions is connected with the growth of innovation.

Rural areas cover the bulk of the surface area of Poland. They consist of utilized agricultural area (52.3\% of the country), forests $(30.2 \%)$, and other land of natural resources and built-up areas, as well as traffic and communicative routes. In Poland, the utilized agricultural areas are constantly shrinking, while the forests are quite stable or even expanding; the share of housing areas and transport routes is increasing. The area of protected sites, claimed as the environmentally valuable, is slightly growing [1].

\subsection{Materials and Methods of the Survey}

There are three unit levels in the administrative division of Poland: voivodeship, district, and commune. The first unit is of a regional character, and the other two are of a local character. There are currently 16 voivodeships, 380 districts, and 2477 communes, including 302 urban communes, 648 urban-rural communes, and 1533 rural communes. The support of rural areas, apart from national 
and regional aid, can be provided by the local authorities of 2181 communes [1]. This is where local innovative systems can be designed, and, apart from the local authorities, local economic and social entities, such as businesses, public organizations and NGOs that operate in communes, should take the lead.

Research on rural areas' development potential encounters many problems connected with the complexity of the issue in question, defining measures of factors and results, absence or questionable credibility of data from local and regional statistics, difficulties in making comparisons across time and space. Methods of analyzing the smart growth of urban areas were adapted when studying the sustainable development of rural areas in the context of a "smart village" [33,51,52]. A thorough analysis of data stored in the Local Data Bank of the Central Statistical Office, Office of Electronic Communications, and the IT system of Central Vehicle and Driver Register was the basis for the present study. Research on innovative potential was performed in six dimensions: management, life quality, economy, society, natural environment, and mobility. Each dimension received adequate weight $(10,20$ or 30). A set of variables describing each dimension suitable for rural conditions was established. Next, all variables were confronted with accessible data sources. A set of 24 variables with a coefficient of variation higher than $10 \%$ and a correlation coefficient less than 0.7 was used in the analysis for the year 2016 and the years 2014-2016. Variables describing different dimensions of the smart village idea are shown in Table 3.

Table 3. Variables describing individual dimensions of the smart village concept ${ }^{*}[23,40]$.

\begin{tabular}{|c|c|c|c|}
\hline $\begin{array}{l}\text { Dimensions of the Smart Village } \\
\text { Concept and Their Weights ** }\end{array}$ & Variable Number & Name and Time Span of Variables & $\begin{array}{l}\text { Weight of the Variable in } \\
\text { the Dimension ** }\end{array}$ \\
\hline \multirow{3}{*}{ Management (10) } & $\mathrm{x}_{1}$ & $\begin{array}{l}\text { Percentage of the councilors representing occupational group of } \\
\text { specialists in total number of councilors (2016) }\end{array}$ & 33 \\
\hline & $\mathrm{x}_{2}$ & $\begin{array}{c}\text { Total value of eligible expenditure in completed projects co-financed } \\
\text { by EU funds within the framework of Innovative Economy, Human } \\
\text { Capital, Infrastructure and Environment, Regional Operational } \\
\text { Program per } 1 \text { resident (2015). }\end{array}$ & 33 \\
\hline & $x_{3}$ & $\begin{array}{l}\text { Percentage of commune area included in existing local plans for } \\
\text { spatial planning in total area of the commune (2016) }\end{array}$ & 33 \\
\hline \multirow{4}{*}{ Life quality (10) } & $\mathrm{X}_{4}$ & Number of economic agents of $Q^{* * *}$ section per 100 residents (2016) & 30 \\
\hline & $X_{5}$ & Number of economic agents of $\mathrm{R} * * *$ section per $100 \mathrm{~km}^{2}(2016)$ & 30 \\
\hline & $\mathrm{x}_{6}$ & Number of specialist labs per 10000 residents (2016) & 20 \\
\hline & $x_{7}$ & $\begin{array}{l}\text { Number of apartments released for use per } 1000 \text { residents } \\
\qquad(2014-2016))\end{array}$ & 20 \\
\hline \multirow{4}{*}{ Economy (30) } & $x_{8}$ & $\begin{array}{l}\text { Percentage of newly registered operators from the food industry } \\
\text { sector in proportion to newly registered operators in total } \\
\text { (2016, rural communes). }\end{array}$ & 30 \\
\hline & $X_{9}$ & $\begin{array}{l}\text { Percentage of operators from sections } \mathrm{J}, \mathrm{K}, \mathrm{L}, \mathrm{M}^{* * *} \text { in proportion to } \\
\text { total number of operators }(2016) .\end{array}$ & 30 \\
\hline & $\mathrm{X}_{10}$ & $\begin{array}{l}\text { Percentage of newly registered operators from the creative sector in } \\
\text { proportion to newly registered operators in total } \\
\text { (2016, rural communes). }\end{array}$ & 20 \\
\hline & $\mathrm{x}_{11}$ & $\begin{array}{l}\text { Percentage of registered unemployed in total number of } \\
\text { populations in the productive age (2016, rural areas). }\end{array}$ & 20 \\
\hline \multirow{6}{*}{ Society (20) } & $\mathrm{X}_{12}$ & $\begin{array}{l}\text { Number of foundations, associations and social organizations per } \\
1000 \text { residents (2016, rural communes) }\end{array}$ & 35 \\
\hline & $\mathrm{X}_{13}$ & $\begin{array}{l}\text { Number of participants in mass events from commune institutions } \\
\text { per } 1000 \text { residents (2014-2016) }\end{array}$ & 20 \\
\hline & $\mathrm{X}_{14}$ & Number of public library loans per 1000 residents (2014-2016) & 15 \\
\hline & $\mathrm{X}_{15}$ & $\begin{array}{l}\text { Percentage of students learning additional foreign languages in } \\
\text { primary schools (2014-2016) }\end{array}$ & 10 \\
\hline & $\mathrm{X}_{16}$ & Number of IT thematic clubs per 1000 residents (2016) & 10 \\
\hline & $\mathrm{X}_{17}$ & Number of U3A members per 1000 residents (2016) & 10 \\
\hline \multirow{3}{*}{ Natural environment (10) } & $\mathrm{X}_{18}$ & Percentage of population using water treatment plant (2016) & 33 \\
\hline & $\mathrm{X}_{19}$ & $\begin{array}{l}\text { Length of sewage line in proportion to the length of water supply } \\
\text { network (percentage, 2016, rural communes) }\end{array}$ & 33 \\
\hline & $X_{20}$ & $\begin{array}{l}\text { Percentage of protected areas (landscape and national parks, as well } \\
\text { as nature reserve) in total commune area (2016) }\end{array}$ & 33 \\
\hline
\end{tabular}


Table 3. Cont.

\begin{tabular}{|c|c|c|c|}
\hline $\begin{array}{l}\text { Dimensions of the Smart Village } \\
\text { Concept and Their Weights ** }\end{array}$ & Variable Number & Name and Time Span of Variables & $\begin{array}{l}\text { Weight of the Variable in } \\
\text { the Dimension ** }\end{array}$ \\
\hline \multirow{4}{*}{ Mobility (20) } & $\mathrm{X}_{21}$ & $\begin{array}{l}\text { Percentage of housing units in the commune within the reach of } \\
\text { Internet NGA in total number of housing units in } \\
\text { the commune (2016) }\end{array}$ & $40(\mathrm{~W}) / 50(\mathrm{G})$ \\
\hline & $x_{22}$ & $\begin{array}{l}\text { Non-urban improved hard surface roads per } 100 \mathrm{~km}^{2}(2016)(\mathrm{W}) \\
* * * * / \text { Number of vehicles registered in the commune per } 1000 \\
\text { residents }(2016)(\mathrm{G})^{* * * *}\end{array}$ & $30(\mathrm{~W}) / 20(\mathrm{G})$ \\
\hline & $x_{23}$ & $\begin{array}{l}\text { Percentage of budget expenditure on transport and communication } \\
\text { in total commune expenditures (2014-2016) }\end{array}$ & 20 \\
\hline & $X_{24}$ & Bicycle lanes length per $10,000 \mathrm{~km}^{2}(\mathrm{~km}, 2016)$ & 10 \\
\hline
\end{tabular}

Data sources: variables $\mathrm{X}_{1}-\mathrm{X}_{20}, \mathrm{X}_{22}(\mathrm{~W}), \mathrm{X}_{23}-\mathrm{X}_{24}$ : Local Data Bank of the Central Statistical Office, variable $\mathrm{X}_{21}$ : Office of Electronic Communications, variable $X_{21}$ : Office of Electronic Communications, variable $X_{22}(G)$ : Central Vehicle and Driver Register. * The metrics have been designed for rural and urban-rural areas, apart from $X_{8}, X_{10}-X_{12}, X_{19} m$, where data for the rural communities were taken into account while performing regional calculations. ${ }^{* *}$ The sum of weights of all dimensions and the sum of weights of variables in dimension $=100$. *** Section J-information and communication, $\mathrm{K}$-finance and insurance, $\mathrm{L}$-real estate market activity, $\mathrm{M}$-occupational, technical and scientific activity, $\mathrm{Q}$-healthcare and social welfare assistance, $\mathrm{R}$-culture, entertainment and recreation (http://www.klasyfikacje.gofin.pl/pkd/4,0.html). ${ }^{* * * *} \mathrm{~W}$ - used in research in the regional sense, G—used in research on rural and urban-rural communes.

"Economy" constitutes 30\% of weight and includes 4 variables (x8-x11), while "society" with less weight has 6 variables (x12-x17). The high rank in "smart village" research was also assigned to mobility ( $20 \%$ of weight and 4 variables). Please note that each of three dimensions had $10 \%$ of share in the explanation of the research results. The set of 24 ratios shown in Table 3 was used for preparing a rural area database for 16 regions in Poland, and 193 communes in Lubelskie voivodeship. Normalization with the use of quotient transformation formula [53] was performed on collected data on the investigated units. The stimulant variables were normalized according to the formula $[23,53]$ :

$$
Z i j=\frac{X i j-\min X i j}{\max X i j-\min X i j}
$$

and the destimulant, variable X11, was normalized according to the following formula:

$$
Z i j=\frac{\max X i j-X i j}{\max X i j-\min X i j}
$$

Normalization satisfied the condition: $Z i j \in[0,1]$.

Having performed the normalization of variables, K. Kukuła's zero unitarization method was applied [53] to create a ranking of objects, considering the potential level of smart development. On the basis of the values of matrix $Z$ elements, including weights applied to variables in each dimension, and weights applied to each dimension, the value of synthetic variable was determined, characterizing each object according to smart growth potential level $[23,53]$ :

$$
Q i=\frac{1}{m} \sum_{j-1}^{m} Z i j \quad(i=1, \ldots, r)
$$

With regard to the calculation of synthetic Qs metrics at the commune level, it should be stressed that each region was considered individually, and the obtained values of smart growth potential synthetic metrics only show the situation of a given territorial unit within a given region.

The communes within each voivodeship on which the study was performed, were classified into five groups showing: very high, high, average, low and very low smart development potential. For this reason, the range of the synthetic variable was obtained through the formula [23,53]:

$$
\mathrm{R}\left(Q_{i}\right)=\max Q_{i}-\min Q_{i}
$$


and designated $k$ parameter of division according to the formula:

$$
k=1 / 5 \mathrm{R}\left(Q_{i}\right)
$$

Five groups of territorial units were extracted on the basis of the following formulas (compare $[23,53])$ :

1. The group with a very high level of smart development potential:

$$
Q_{i} \in\left[\max Q_{i}-k, \max Q_{i}\right]
$$

2. The group with a high level of smart development potential:

$$
Q_{i} \in\left[\max Q_{i}-2 k, \max Q i-k\right]
$$

3. The group with an average level of smart development potential:

$$
Q i \in[\max Q i-3 \mathrm{k}, \max Q i-2 k]
$$

4. The group with a low level of smart development potential:

$$
Q i \in[\max Q i-4 k, \max Q i-3 k]
$$

5. The group with a very low level of smart development potential:

$$
Q i \in[\max Q i-3 k, \max Q i-2 k]
$$

Collective results of clustering rural and urban-rural communes in the three regions are presented in Table 4. The high level of Qs synthetic metrics value in Warmińsko-Mazurskie should draw special

\begin{tabular}{|c|c|c|c|c|c|c|c|c|c|}
\hline \multirow{3}{*}{$\begin{array}{l}\text { Class of Qs } \\
\text { Synthetic } \\
\text { Metrics Value } \\
\text { for Smart } \\
\text { Growth }\end{array}$} & \multicolumn{9}{|c|}{ Class Characteristics of Qs Metrics Values by Voivodeship } \\
\hline & \multicolumn{3}{|c|}{ Lubelskie } & \multicolumn{3}{|c|}{ Podkarpackie } & \multicolumn{3}{|c|}{ Warmińsko-Mazurskie } \\
\hline & $\begin{array}{l}\text { Scope of Qs } \\
\text { Metrics } \\
\text { Value }\end{array}$ & $\begin{array}{l}\text { Number of } \\
\text { COMMUNEs }\end{array}$ & $\begin{array}{l}\text { Communes } \\
\text { Share (\%) }\end{array}$ & $\begin{array}{c}\text { Scope of } \\
\text { Qs Metrics } \\
\text { Value }\end{array}$ & $\begin{array}{l}\text { Number of } \\
\text { Communes }\end{array}$ & $\begin{array}{c}\text { Communes } \\
\text { Share }(\%)\end{array}$ & $\begin{array}{l}\text { Scope of } \\
\text { Qs Metrics } \\
\text { Value }\end{array}$ & $\begin{array}{l}\text { Number of } \\
\text { Communes }\end{array}$ & $\begin{array}{c}\text { Communes } \\
\text { Share }(\%)\end{array}$ \\
\hline very high & $\begin{array}{c}\text { Qs } \in<0.37 \\
0.43>\end{array}$ & $7(5) *$ & 3.6 & $\begin{array}{c}\text { Qs } \in<0.35 \\
0.41>\end{array}$ & $3(0)$ & 2.1 & $\begin{array}{c}\text { Qs } \in<0.48 \\
0.57>\end{array}$ & $1(0)$ & 1.0 \\
\hline high & $\begin{array}{c}\text { Qs } \in<0.31 \\
0.37)\end{array}$ & $35(10)$ & 18.1 & $\begin{array}{c}\text { Qs } \in<0.29 \\
0.35)\end{array}$ & $34(15)$ & 23.6 & $\begin{array}{c}\mathrm{Qs} \in<0.39 \\
0.48)\end{array}$ & $5(5)$ & 5.0 \\
\hline average & $\begin{array}{c}\text { Qse< } 0.25 \\
0.31)\end{array}$ & $66(5)$ & 34.2 & $\begin{array}{c}\text { Qs } \in<0.23 \text {; } \\
0.29)\end{array}$ & $53(16)$ & 36.8 & $\begin{array}{c}\text { Qs } \in<0.29 \\
0.39)\end{array}$ & $27(16)$ & 27.0 \\
\hline low & $\begin{array}{c}\text { Qs } \in<0.19 \\
0.25)\end{array}$ & $69(6)$ & 35.8 & $\begin{array}{c}\text { Qs } \in<0.17 \\
0.23)\end{array}$ & $49(4)$ & 34.0 & $\begin{array}{c}\mathrm{Qs} \in<0.20 \\
0.29)\end{array}$ & $40(11)$ & 40.0 \\
\hline very low & $\begin{array}{c}\mathrm{Qs} \in<0.13 \\
0.19)\end{array}$ & $16(0)$ & 8.3 & $\begin{array}{c}\mathrm{Qs} \in<0.10 \\
0.17)\end{array}$ & $5(0)$ & 3.5 & $\begin{array}{c}\mathrm{Qs} \in<0.11 \\
0.20)\end{array}$ & $27(1)$ & 27.0 \\
\hline total & & $193(26)$ & 100 & total & $144(35)$ & 100 & total & $100(33)$ & 100 \\
\hline
\end{tabular}
attention. This region represents the highest level of smart development potential, while Podkarpackie represents the lowest one. This paper presents clustering results only for Lubelskie voivodeship, which represents the average level of smart rural development potential.

Table 4. Size of groups of territorial units, selected on the basis of synthetic metrics for smart growth potential in communes in Lubelskie, Podkarpackie, and Warmińsko-Mazurskie [23].

* Number of urban-rural communes given in brackets.

Structure types of potential for rural areas' smart growth in Poland were separated by means of the k-means clustering method, with the use of observations maximizing cluster distance. Cluster analysis includes many different classification algorithms for taxonomic purposes. In k-means grouping, the program tries to move objects to and from groups (clusters) to obtain the most important results of analysis of variance. After adopting the hypothesis on the number of case clusters, the k-means method allows for the creation of k-clusters that differ as much as possible from one another [54]. 
Finally, the grouping results obtained for five clusters were adopted. Statistica 10 software was used for the calculations.

\section{Results}

\subsection{The Potential for the Smart Growth of Rural Areas in Regions of Poland}

The aim of the research on the potential for the smart growth of rural areas in all regions of Poland was to distinguish the structural types of such potential. For this purpose, k-means clustering was applied. Variables constituting synthetic, weighted values of the six above-mentioned dimensions were used for clustering. The synthetic values of investigated dimensions are illustrated in Figure 2. It is worth mentioning that three regions-Opolskie, Dolnoślaskie and Wielkopolskie-have high potential for smart development in the economic dimension, while, in the social dimension, high values are exhibited by two regions: Dolnośląskie and Zachodniopomorskie. Podkarpackie shows the highest potential in the natural environment, Ślaskie in mobility, and Pomorskie in the life quality dimension.

Characteristics of separated clusters reflecting structural types of the potential for the smart growth of rural areas are presented in Table 5.

Sixteen Polish regions (voivodeships) were divided into five clusters. Cluster 1-5 showed high levels of sustainable potential of smart solutions in the analyzed dimensions. The highest values concerning the potential for smart growth in economy, management and natural environment were observed in Cluster 5, which included Opolskie and Ślaskie. Slightly lower values in these dimensions, and at the same time the highest ones for smart growth potential in the social sphere, were found in Cluster 1, which included Dolnośląskie, Lubuskie and Wielkopolskie. Sustainable potential for smart growth at an average level, with distinctive potential in life quality, was the characteristic feature of rural areas belonging to Cluster 2: Kujawsko-pomorskie, Małopolskie, Pomorskie and Zachodniopomorskie. The remaining clusters were characterized by the lowest level of synthetic metrics of the potential in the analyzed dimensions. In the case of Cluster 4, including voivodeships such as Łódzkie, Mazowieckie and Podlaskie, relatively poorer conditions in terms of management, natural environment and society appeared in the structure of the potential for the smart growth of rural areas. Finally, Cluster 3 comprised four voivodeships situated in Eastern Poland. In this group, the potential for the smart growth of rural areas revealed relatively poorer conditions for smart solutions in the field of economy, life quality and mobility. F values and statistical significance indicate that economy and mobility were the main criteria in assigning voivodeships to particular clusters. The dimension of management and natural environment was not decisive in the process of clustering [23].

\subsection{The potential for the Smart Growth of Rural Areas in Peripherial Regions of Poland}

On the basis of the procedure described above, three border voivodeships, classified as Cluster 3 , were selected for empirical research: Lubelskie, Podkarpackie and Warmińsko-Mazurskie. These three voivodeships, together with Podkarpackie and Świetokrzyskie, belong to the region called Eastern Poland, which is recognized as one of the least developed regions in the European Union. The cluster in question was characterized by potential for smart development of rural areas showing relatively poorer conditions for economy, life quality and mobility in comparison with the remaining regions [23]. The values of synthetic metrics for smart growth in the analyzed dimensions indicate some differences between the regions selected for the study (Figure 3). 


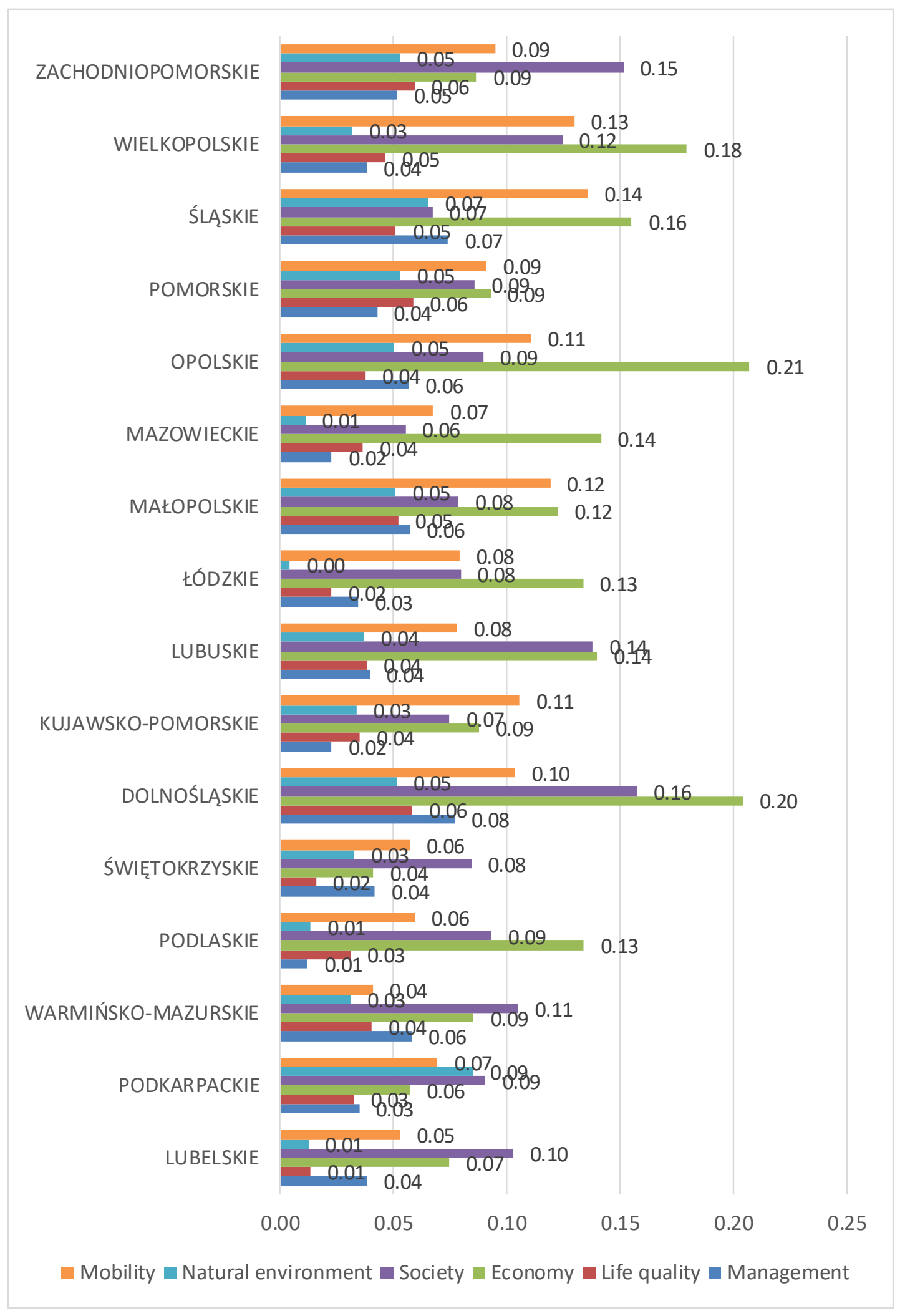

Figure 2. Synthetic values of investigated dimensions of the potential for smart development of rural areas by region in Poland [23]. 
Table 5. Characteristics of separated clusters reflecting structural types of the potential for the smart growth of rural areas * [23].

\begin{tabular}{|c|c|c|c|c|c|c|c|c|c|c|c|c|}
\hline \multirow{4}{*}{ Smart Growth Dimensions } & \multicolumn{10}{|c|}{ Arithmetic Means of Synthetic Metrics by Number, Name and Cluster Elements } & \multirow{4}{*}{ F } & \multirow{4}{*}{$p$} \\
\hline & \multirow{2}{*}{\multicolumn{2}{|c|}{$\begin{array}{c}\text { 1-Sustained Potential at a High Level, } \\
\text { With Distinctive Social Sphere } \\
\text { Dolnoślaskie, } \\
\text { Lubuskie, } \\
\text { Wielkopolskie }\end{array}$}} & \multirow{2}{*}{\multicolumn{2}{|c|}{$\begin{array}{c}\text { 2-Sustainable Potential at an } \\
\text { Average Level with } \\
\text { Distinctive Life Quality } \\
\text { Kujawsko-Pomorskie, } \\
\text { Małopolskie, } \\
\text { Pomorskie, } \\
\text { Zachodniopomorskie }\end{array}$}} & \multirow{2}{*}{\multicolumn{2}{|c|}{$\begin{array}{c}\text { 3-Potential Showing } \\
\text { Relatively Poorer Conditions } \\
\text { in Terms of Economy, Life } \\
\text { Quality and Mobility } \\
\text { Lubelskie, } \\
\text { Podkarpackie, } \\
\text { Sowietekrzyskie, } \\
\text { Warmińsko-Mazurskie } \\
\end{array}$}} & \multirow{2}{*}{\multicolumn{2}{|c|}{$\begin{array}{c}\begin{array}{c}\text { 4-Potential Showing } \\
\text { Relatively Poorer Conditions } \\
\text { in terms of Management, } \\
\text { Natural Environment, Society }\end{array} \\
\begin{array}{c}\text { Łódzkie, } \\
\text { Mazowieckie, } \\
\text { Podlaskie }\end{array} \\
\end{array}$}} & \multicolumn{2}{|c|}{$\begin{array}{c}\text { 5-Sustainable Potential at a } \\
\text { High Level }\end{array}$} & & \\
\hline & & & & & & & & & \multicolumn{2}{|c|}{$\begin{array}{l}\text { Opolskie, } \\
\text { Sląskie }\end{array}$} & & \\
\hline & Mean Average & $\begin{array}{l}\text { Standard } \\
\text { Deviation }\end{array}$ & $\begin{array}{c}\text { Mean } \\
\text { Average }\end{array}$ & $\begin{array}{l}\text { Standard } \\
\text { Deviation }\end{array}$ & $\begin{array}{c}\text { Mean } \\
\text { Average }\end{array}$ & $\begin{array}{l}\text { Standard } \\
\text { Deviation }\end{array}$ & $\begin{array}{c}\text { Mean } \\
\text { Average }\end{array}$ & $\begin{array}{l}\text { Standard } \\
\text { Deviation }\end{array}$ & $\begin{array}{c}\text { Mean } \\
\text { Average }\end{array}$ & $\begin{array}{l}\text { Standard } \\
\text { Deviation }\end{array}$ & & \\
\hline Management & 0.0517 & 0.0220 & 0.0437 & 0.0151 & 0.0433 & 0.0102 & 0.0233 & 0.0111 & 0.0655 & 0.0123 & 2.769 & 0.0815 \\
\hline Economy & 0.1746 & 0.0324 & 0.0975 & 0.0169 & 0.0647 & 0.0195 & 0.1364 & 0.0045 & 0.1812 & 0.0367 & 15.768 & 0.0002 \\
\hline Society & 0.1400 & 0.0166 & 0.0978 & 0.0361 & 0.0958 & 0.0099 & 0.0761 & 0.0192 & 0.0785 & 0.0158 & 3.598 & 0.0414 \\
\hline Natural environment & 0.0403 & 0.0101 & 0.0477 & 0.0093 & 0.0405 & 0.0313 & 0.0098 & 0.0047 & 0.0580 & 0.0105 & 2.784 & 0.0805 \\
\hline Mobility & 0.1039 & 0.0258 & 0.1027 & 0.0126 & 0.0552 & 0.0118 & 0.0688 & 0.0099 & 0.1233 & 0.0177 & 9.556 & 0.0014 \\
\hline
\end{tabular}

* Minimum and maximum values of arithmetic mean of the metrics in compared groups are gray shaded. 


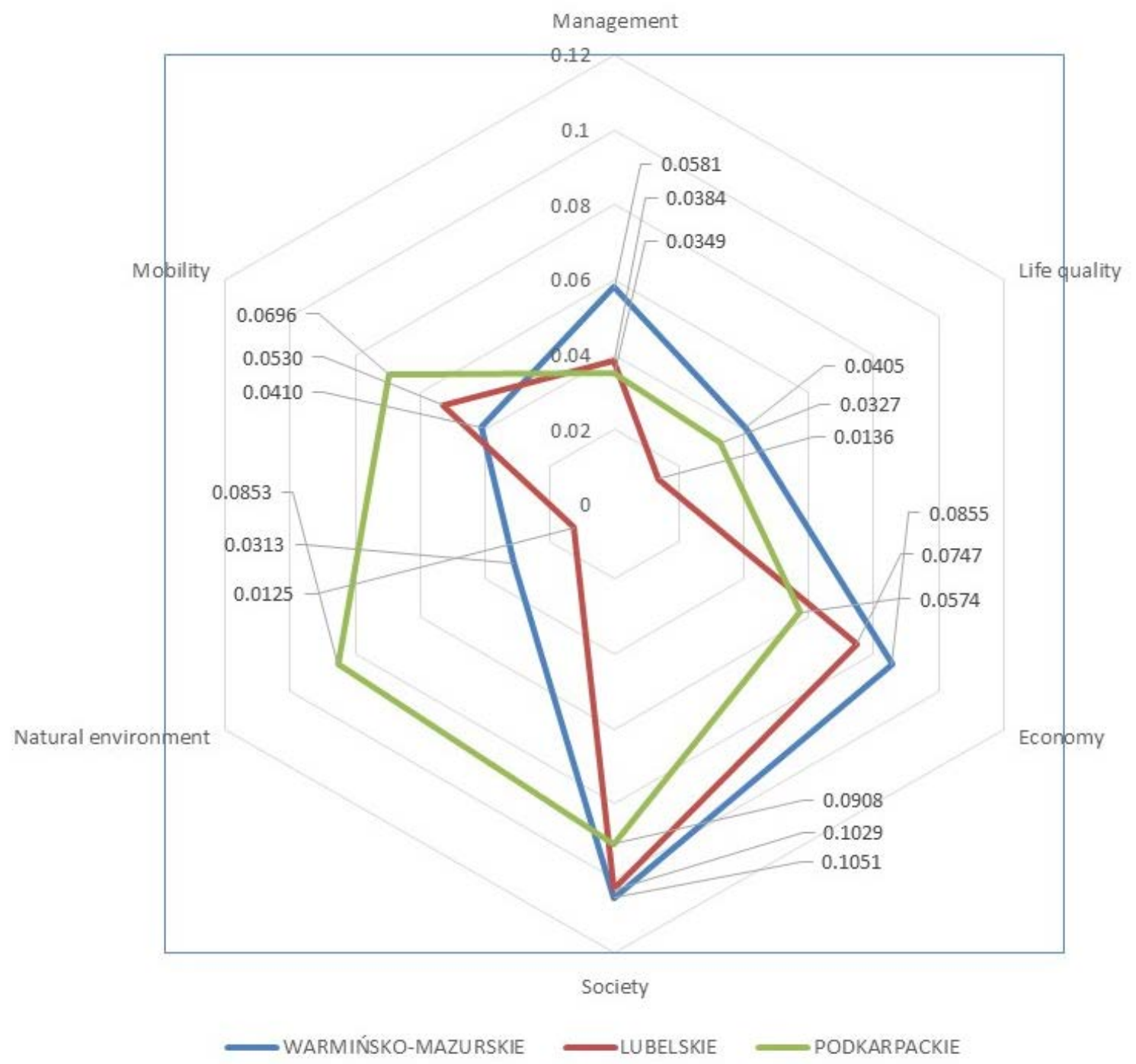

Figure 3. Profile characteristics of voivodeships selected for the study according to the dimensions of smart growth [23].

The voivodeships selected for research presented similar conditions in the field of potential for smart solutions in society. With regard to the economy, Warmińsko-Mazurskie and Lubelskie showed similar potential for smart solutions. Less favorable conditions were present in Podkarpackie. The potential for smart growth in the field of life quality was similar in Warmińsko-Mazurskie and Podkarpackie. Less favorable conditions in this area were observed in Lubelskie. The potential for smart solutions in management reached its outstanding value in Warmińsko-Mazurskie, like Podkarpackie in mobility, and Podkarpackie in terms of the natural environment [23].

Research on smart growth potential was conducted in 10 communes in each of the three voivodeships located in the macro-region called Eastern Poland. All 30 communes in the three regions were assigned to Cluster 3 . They are comparatively similar in the social dimension and diversified with regard to natural environment. It is assumed that these regions are representing a lower level of economic development and quality of life, low mobility of population and a peripheral location. 
The elements of the regions' characteristics enable us to classify these regions as peripheral. The peripherality of the regions is revealed both in the spatial dimension, determined by the location in the eastern part of Poland and the European Union (these are regions constituting the borders of the EU), as well as in the economic and socio-demographic dimension. They belong to the least-developed voivodeships of Poland and, at the same time, to the least-developed regions of the European Union-lagging regions (low-income regions). Lagging regions present lower productivity, educational attainment and employment rates compared to other regions in the same country. They also score poorly on labor market and business dynamics indicators. Low-income regions are all regions with a per capita GDP in PPS below 50\% of the EU average in 2013. This group covers several less developed regions in Bulgaria, Hungary, Poland and Romania [55].

Peripherality is a multidimensional phenomenon. It can be viewed at the level of geographic and communication location (e.g., distance from centers of political, administrative and socio-economic life), economy (low economic potential and ineffective economic structure), socio-demography (low population density, progressive depopulation processes, low quality of social capital associated with a low level of trust and social cooperation, as well as cultural peripherality), administration and politics (e.g., low strategic importance of the area on the international or national scale), as well as historical and geopolitical conditions [56]. Development-related problems of peripheral areas are endogenous and related to the inability to generate agglomeration effects, and to the limitations of institutional potential [57]. They are characterized by restricted potential of innovative processes and a lower rate of innovative activity compared to core areas [58,59]. According to literature, peripheral areas are characterized by considerable diversity, which should be taken into account while formulating a development policy $[60,61]$. There have been some attempts for the EU area to measure peripherality [62].

Mean values of variables describing individual dimensions in the voivodeships in question are shown in Table 6. Warmińsko-Mazurskie voivodeship took the lead in potential values concerning the introduction of changes to life quality, society, management. In Lubelskie, low level of smart solutions potential for life quality was accompanied by relatively high values of synthetic metrics referring to society, while Podkarpackie had relatively low potential for economy and a high level for the natural environment, mobility and management compared to other regions of Eastern Poland [23].

Communes in each of the regions were selected for empirical study by drawing five communes out of two extreme classes of Qs metrics value for smart development. In this article, we present research results only for communes in Lubelskie. They are listed in Table 7.

The communes in Lubelskie voivodeship, classified as those with the highest potential for the smart growth of rural areas, yielded equal results concerning potential for management. By reaching the highest value of the Qs synthetic metrics in the region, Janów Lubelski excelled in the potential for smart solutions concerning natural conditions, life quality and social dimension. Jastków commune, located in the vicinity of the voivodeship capital, the city of Lublin, was characterized by high potential for economy and life quality compared to the remaining communes. In turn, Parczew and Poniatowa were the communes that showed an outstanding mobility potential. Quite high potential for economy and society was assigned to Milejów, a commune with a very long tradition of fruit and vegetable processing [23]. 
The group of communes representing class 5, with very low values of Qs synthetic metrics, was generally characterized by remoteness from larger, sub-regional urban areas. With regards to the potential for smart solutions concerning the economy, the Abramów commune, located near the important Warsaw-Lublin transport route, and the Nielisz commune, situated $20 \mathrm{~km}$ from Zamość-the capital of the district—revealed the most distinctive results [23] (Figure 4).

Table 6. Mean values of variables describing particular dimensions in the smart village concept by region [23].

\begin{tabular}{|c|c|c|c|c|}
\hline \multirow{2}{*}{ Dimensions of Smart Village Concept } & \multirow{2}{*}{$\begin{array}{l}\text { Variables } \\
\text { Number }\end{array}$} & \multicolumn{3}{|c|}{ Voivodeship } \\
\hline & & Lubelskie & Podkarpackie & Warmińsko-Mazurskie \\
\hline \multirow{3}{*}{ management } & $\mathrm{X}_{1}$ & 12.62 & 18.53 & 19.97 \\
\hline & $x_{2}$ & 4081.75 & 5089.39 & 7713.04 \\
\hline & $x_{3}$ & 57.58 & 8.12 & 12.14 \\
\hline \multirow{4}{*}{ life quality } & $\mathrm{X}_{4}$ & 0.25 & 0.27 & 0.39 \\
\hline & $X_{5}$ & 6.53 & 12.55 & 4.86 \\
\hline & $x_{6}$ & 2.50 & 3.28 & 4.23 \\
\hline & $x_{7}$ & 2.47 & 2.80 & 2.91 \\
\hline \multirow{4}{*}{ economy } & $\mathrm{X}_{8}$ & 0.63 & 0.42 & 0.55 \\
\hline & $x_{9}$ & 10.49 & 11.06 & 16.16 \\
\hline & $X_{10}$ & 4.47 & 4.81 & 3.79 \\
\hline & $X_{11}$ & 7.42 & 8.67 & 9.37 \\
\hline \multirow{6}{*}{ society } & $\mathrm{X}_{12}$ & 3.26 & 3.16 & 3.45 \\
\hline & $x_{13}$ & 889.70 & 1108.45 & 908.94 \\
\hline & $\mathrm{X}_{14}$ & 2693.12 & 2521.06 & 2234.50 \\
\hline & $\mathrm{X}_{15}$ & 11.51 & 5.52 & 5.15 \\
\hline & $x_{16}$ & 0.15 & 0.05 & 0.29 \\
\hline & $\mathrm{X}_{17}$ & 2.06 & 1.79 & 2.19 \\
\hline \multirow{3}{*}{ natural environment } & $\mathrm{X}_{18}$ & 31.44 & 61.54 & 59.81 \\
\hline & $\mathrm{X}_{19}$ & 22.41 & 113.93 & 33.41 \\
\hline & $x_{20}$ & 10.74 & 19.30 & 7.07 \\
\hline \multirow{4}{*}{ mobility } & $x_{21}$ & 27.42 & 38.78 & 38.03 \\
\hline & $x_{22}$ & 72.6 & 72.7 & 43.40 \\
\hline & $x_{23}$ & 7.90 & 6.58 & 6.09 \\
\hline & $x_{24}$ & 118.08 & 119.84 & 113.57 \\
\hline
\end{tabular}

Table 7. Set of ten communes selected for analysis in Lubelskie by district, type, class and value of $Q s$ metrics [23].

\begin{tabular}{ccccc}
\hline Commune & District & Type of Commune & Qs Metrics Class & Qs Metrics Value \\
\hline Janów Lubelski & janowski & urban-rural & 1 & 0.415 \\
Parczew & parczewski & urban-rural & 1 & 0.389 \\
Milejów & łęczyński & rural & 1 & 0.380 \\
Poniatowa & opolski & urban-rural & 1 & 0.369 \\
Jastków & lubelski & rural & 1 & 0.369 \\
Nielisz & zamojski & rural & 5 & 0.184 \\
Stary Brus & włodawski & rural & 5 & 0.172 \\
Abramów & lubartowski & rural & 5 & 0.170 \\
Dzwola & janowski & rural & 5 & 0.165 \\
Leśniowice & chełmski & rural & 5 & 0.153 \\
\hline
\end{tabular}


Taking into account the spatial location of communes representing different classes of Qs synthetic metrics value, we may identify some of its regularities referring to the three analyzed regions (Figure 5). In the case of Lubelskie, the units with the highest-class values of Qs metrics had a tendency to concentrate in the central and south-east part of the region. In this voivodeship, the role of large and medium urban centers in the creation of favorable conditions for rural and urban-rural communes to shape smart growth potential has become clearly visible. This especially holds true for the capital of the region, Lublin, but also for Lubartów, Ryki, Puławy or Kraśnik, around which the units with the highest-class values of Qs metrics are concentrated. Another characteristic feature of territorial units with very high and high values of Qs synthetic metrics is the presence of their groups in areas beyond the direct influence of larger urban areas, e.g., Rossosz, Wisznice and Jabłon, or Zwierzyniec, Krasnobród, Józefów, Susiec and Łukowa. High smart development potential is also created by single communes that usually exhibit the elements of local potential used in the creation of development processes, which are recognizable on the regional scale and more widely. Examples of such communes include Terespol, Janów Podlaski and Janów Lubelski. When describing the spatial diversity of units on a different level of smart development potential, we should also notice the lack of beneficial influence of medium-sized towns on smart growth potential of adjacent territorial units. Such situation exists mainly in the east and south-east part of the region. A higher concentration of communes with a very high and high level of smart development potential may be observed in the area surrounding Lublin, the capital of the region, and along the route connecting Lublin with Warsaw, the capital of the country [23].

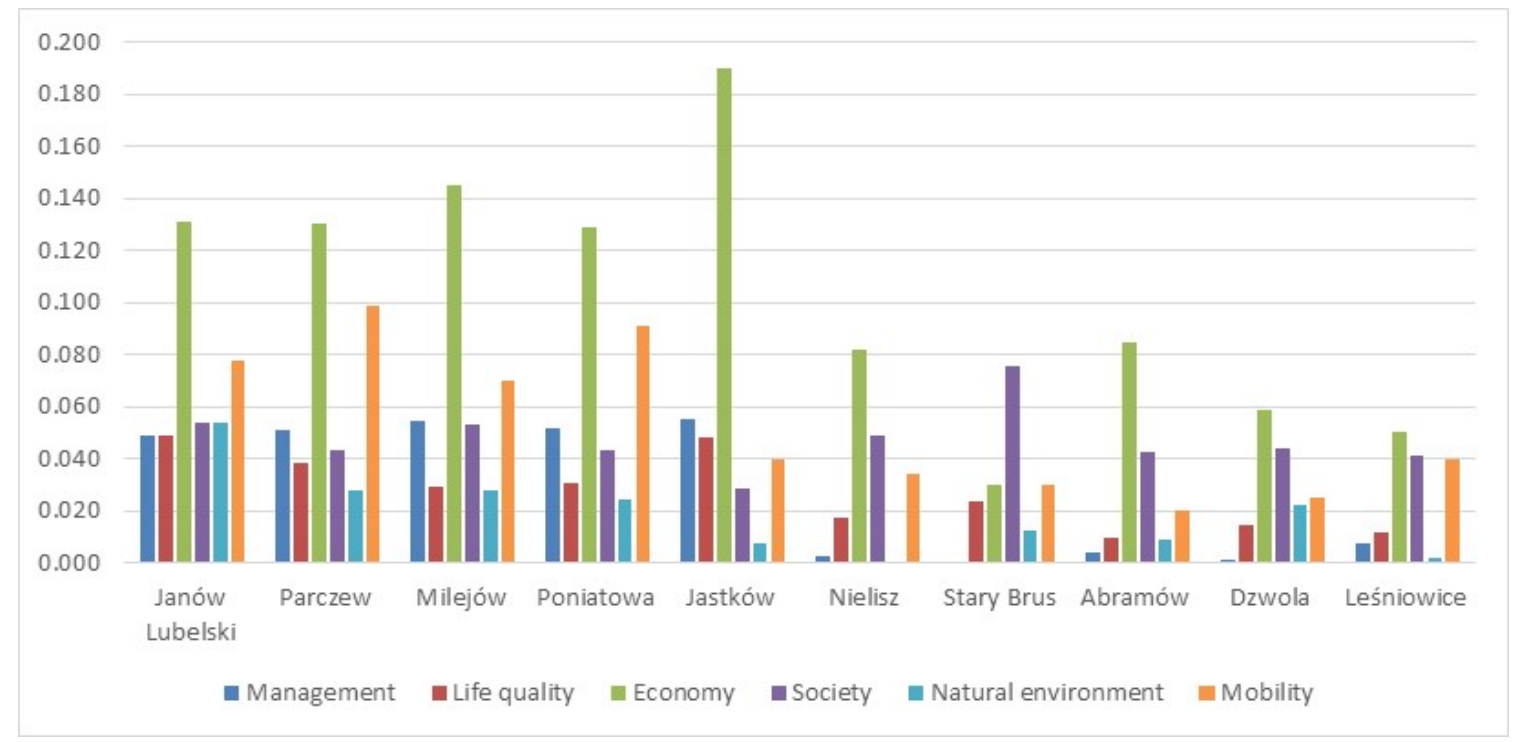

Figure 4. Values of synthetic metrics of smart growth potential in communes in Lubelskie, according to the investigated dimensions of smart solutions' potential [23]. 


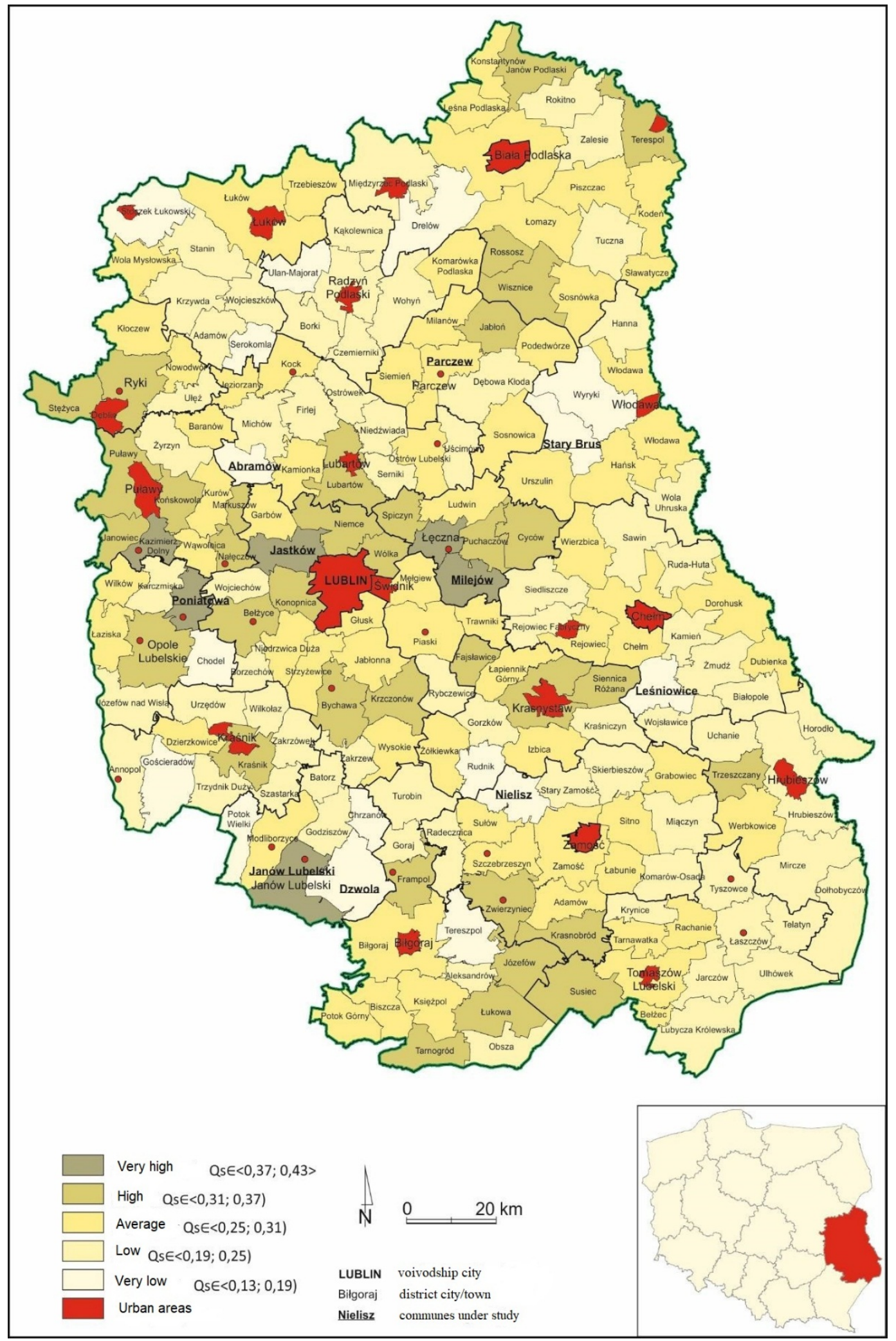

Figure 5. Rural and urban-rural communes in Lubelskie voivodeship according to the class of the value of Qs synthetic metrics of smart growth potential [23]. 


\section{Discussion}

Permanent and sustainable growth is widely considered a theoretical basis and a practical hint for formulating plans, programs, strategies and development policies on the global, country, regional and local scale. This also, or even in particular, applies to rural areas, which cover the majority of the surface of every country. It also refers to agriculture, forestry and other sectors that make extensive use of natural resources. Nowadays, blending innovative methods, techniques, action patterns and social attitudes facilitating development in the local socio-economic environment into the processes of sustainable development is a significant feature. A better use of knowledge and innovations in the development of local systems could be an important factor in the increase of their competitiveness. This refers both to urban and rural areas.

The socio-economic growth of rural areas is connected with the quantitative and qualitative changes in methods and results of economic management, and relations between the production factors. In the local environment, the creation of such economic and social structures which are able to generate income for the residents, satisfy their diversified aspirations, improve access to goods and public services, at the same time alleviating the negative impact of phenomena such as rural economy monofunctionality, depopulation or unemployment $[23,63,64]$ should be the objective of the development processes. From another point of view, the development of rural areas can be defined as a multilevel, multiagent and multiway process of the creation of new products and services, and the markets connected with them.

New theories of growth and institutional changes reveal the need for building comprehensive innovations systems at different levels of a country's territorial division $[65,66]$. National, regional and local innovation systems can be created. They can be general or pertain to urban and rural areas separately. Rural innovation systems are especially important for local and regional systems. They are created by numerous external agents, as well as those within a given system (public and local authority organizations, businesses, intermediate and supportive bodies, family-run businesses, etc.), which are interested in satisfying their own and local needs, as well as achieving development goals with the use of local resources and competence for the creation and diffusion of new ideas, solutions, and methods of functioning (innovative products, services, methods of functioning, new organizational solutions, etc.). These systems, created by establishing working connections between sectors such as knowledge, science and education (the main source of innovation), management and functioning of local agents and institutions which use innovations, financial and service agency sectors, which take part in the transfer and absorption of innovations, adapted to the conditions and needs of particular socio-economic ecosystems, should ensure stability and sustenance of rural areas in a given system. One of the tasks for local innovation systems is the provision and improvement of local/regional infrastructure to enhance the innovative potential of a given area. Their specific goals can include the regeneration of rural areas, building modern villages or executing other specialized programs reinforcing the stability and sustainable growth of a given area.

An analysis of the contemporary development processes of rural areas reveals the fact that the structure of their functions is undergoing some crucial changes. It seems that the role of production functions of agriculture is being limited. At the same time, the importance of non-agricultural roles, especially those concerning non-agricultural economic sectors in rural areas, is increasing. Forestation and non-productive functions of forests are maximized; agritourism is developing; and the general environmental, social and cultural functions of rural areas obtain their broader significance. As a consequence, the perception of sustainability and persistence of rural areas concept is changing, as reflected in the shape of policy concerning rural areas and agriculture $[23,67]$. The idea of sustainable development formulated in the 1980s has become a key element of policies, plans and development strategies on all levels, and in social sciences it has become the core of the new development paradigm $[10,14,68]$.

Rural sustainability can be developed in different ways, and specific theoretical concepts still do not give integrated and universal guidance for practical implementation of rural sustainability. 
The concept of a smart village is one which seems to be useful in Polish conditions. This form of rural development is adopted in the variety of implementations in different countries. This can be proved when the success of the LEADER program in different western and eastern European countries has been discussed $[31,46,48]$. The idea of a smart village as a form of sustainable, smart rural development seems to be successful in less developed regions in eastern European countries [28,40,68-71]. The study concludes that the selected regions and communities in Poland exhibit high differentiation of regions and commune's potential for smart, sustainable rural development. This potential is influenced mainly by economic and social dimensions, as well as by mobility. The development of local smart village projects, which requires the application of new technologies, digitalization and networking, has more favorable conditions in locations closer to bigger cities and economic activity centers. The research conducted in Lublin voivodeship in Poland reveals that rural areas adjacent to urban development centers offer the greatest possibilities to adapt the idea of smart growth. It can be observed that they are places with strong influence of urban areas, a certain integration of a village and a city with numerous population, absorptive selling market, a well-developed industry and services base, as well as agents and institutions creating innovations. Hence, the vicinity of urban areas ensures several natural, technological, recreational and cultural amenities, as well as easy access to tools enabling the development of cooperative networks, necessary to create smart forms of the organization of rural life.

The concept in question has laid foundations for several specific concepts focusing on certain parts or methods of action required for its execution. One of them was the idea of multi-functional development, which, if treated in a broader sense, including a vast selection of a rural area's functions, can be considered one of the foundations for sustainable development. It concerns both the multi-functionality of rural areas and agriculture or forestry [72]. The fundamental elements of this attitude are local businesses, agricultural and non-agricultural diversification in rural areas, and the development of infrastructure and social capital.

The holistic approach towards local development constitutes yet another concept of the bottom-up or endogenous growth. It is based on the use of local resources and endogenous potential in order to build the area capital of a given system, in a kind of symbiosis of rural areas with larger residential and urban areas. In this case the sectoral approach is replaced by a sectional view oriented towards achieving the territorial cohesion. A modified version of this idea, the neo-endogenous approach, concentrates to a larger extent on the need of integrated connections, not only internal, but also external, including web network systems. The rural web, from a theoretical point of view, is the combination of six dimensions: endogeneity, innovation, social capital, market management, institutional solutions, and sustainable development. In practice, it is made of interactions and connections, as well as mutual standards and integrated actions of agents, including all sectors, resources and geographical regions [73]. Without going into detail, it should be stressed that innovations and innovativeness are the key elements of it. A successful implementation of innovations requires both the consistency of agents acting for rural areas, as well as a high level of culture, cooperation, dialog and communication. The potential for development synergy is reinforced through building the social capital.

Smart growth means strengthening knowledge and innovation as the driving force for future development. This requires better education, intensifying scientific research, promoting innovations, transfer of knowledge across countries, making full use of information and communication technologies, and ensuring the transformation of innovative ideas into new products and services that will contribute to economic growth, structural changes, quality improvement and meeting various challenges of contemporary world. The activities for smart growth and development can be implemented at the EU, national, regional and local levels. In fact, the smart village method can help to stimulate the development of rural areas in peripheral regions as well as in others. In less developed, low-urbanized regions, adequate support policy is necessary.

This also means that while designing strategies for sustainable rural development, it must be kept in mind that one particular strategy will not work in the same way everywhere because of 
accompanying changes. This is especially the case when the strategy from one region or country is to be transferred to another place. However, after adjustment for regional and local conditions, the idea of a smart village might be successfully implemented everywhere. The adoption of such a new concept requires adequate access to telecommunication infrastructure, active participation of business units, local institutions and citizens under the supportive policy of regional and central governments. Conducting research and efficient extension by means of different tools, including case studies and pilot projects, may increase the scale and efficiency of the ideas in question.

\section{Conclusions}

The general goals and means of the sustainable development of rural areas can be attained in many different ways. One of the promising forms facilitating the process of sustainable development of rural areas is the smart village concept, as well as the implementation of smart specializations of regions and local systems. The idea combines the need to base the development on endogenous resources triggered bottom-up, with the necessity of maintaining and developing external connections and benefiting from exogeneous innovative potential. In the smart village concept, local resources and specific and original competence reinforced by building social and human capital, developing the co-operation network and building local innovations systems can be better used for enhancing the system's competitiveness, economic growth, improvement of living conditions, and the functioning of the economy, through increased absorption of technical and social innovations and multi-directional, internal and external cooperation. Rural areas located within the area of influence of large urban agglomerations have more favorable conditions for the practical implementation of the smart village concept, mainly due to better endowment and better access to new digital and professional technologies, networking institutions and closer distance to expert and management services. Agricultural areas, on the other hand, can successfully adopt smart production specializations, mainly in agricultural and bioeconomy fields.

The assimilation of the smart village concept is to a large extent conditioned by the localization, as well as social and economic specific nature of the area, defined by the character of a given local system and its local community. The vulnerability of the particular community, the ability to absorb innovations and the skill of their acquisition are very important. Successful implementation of innovations should take into account the socio-economic specialization of the commune, the needs of residents and local economy, access to innovations sources, as well as management methods and skills. Formalizing actions leading to building the innovative potential of smart villages can be achieved by creating and adopting documents defining strategy and development policy of the commune as the basic unit of the territorial system in a country.

In order to further enhance smart development of rural areas and to implement smart village projects in practice, it is necessary to conduct research on the state, factors, forms, and consequences of such growth. The key issue is the selection of analyzed variables and their quantification, with the existing loopholes in accessible statistics and IT databases. Research on the sustainable development of rural areas and agriculture has been conducted for many years. In Poland, in the years 2017-2020, it was supplied with the findings concerning shaping regional and local innovations systems and smart villages, as a new way for building resilience and sustainability of rural areas. The partial results of such research, which are presented in this paper, reported for three voivodeships located close to Poland's eastern border, are promising and should be continued. They confirmed the usefulness of the smart village concept as a way of building local innovations systems and supporting rural areas in peripheral regions.

The method used in empirical research makes it possible to evaluate and analyze the state of differentiation in the conditions of smart growth potential. It can be applied in regional development policy in various ways-both as a part of regional, internal policy covering the entire region, and in relation to its individual local units. Such analysis may constitute an important tool to diagnose the development potential of a given territory, in terms of the implementation of tasks that lead 
to the increase in the potential to use development opportunities. They in turn may result from the use of endo- and exogenous factors of regional and local development, which originates in contemporary development conditions, including globalization, and the popularization of ICT technologies. This method can be used by both local and regional government authorities, as well as entities cooperating with them, actively participating in development processes. They include policy decision makers, agents for regional and local development, planners and evaluators, as well as scientists interested in rural development.

Summing up, it can be claimed that the smart village concept, though not universal, takes on challenges of the contemporary world, which result from the strengthening of the economy based on knowledge, using technological and social innovations, as well as network connections. It also encourages the enhancement of the competitiveness of rural areas in local, regional, country and global systems. Being territorially empowered and locally rooted, the idea accentuates care not only for the countryside residents' life quality and work conditions, but also the natural and cultural environment. For this reason, it can be broadly used in formulating policies and development strategies aimed at strengthening the persistence and sustainability of rural areas.

The sustainability of rural areas, as well as different forms, methods and tools applied in rural development, requires further, more systematic research. The methods used in projects constituting the basis of this article proved to be one of the successful approaches to research on a broader, international scale.

Author Contributions: Conceptualization, M.A. and M.Z.-L.; methodology, M.A. and M.Z.-L.; software, M.Z.-L.; validation, M.A. and M.Z.-L.; formal analysis, M.A. and M.Z.-L.; investigation, M.A. and M.Z.-L.; resources, M.A. and M.Z.-L.; data curation, M.A. and M.Z.-L.; writing - original draft preparation, M.A.; writing-M.A. and M.Z.-L.; visualization, M.Z.-L.; supervision, M.A. and M.Z.-L.; project administration, M.Z.-L.; funding acquisition, M.Z.-L. All authors have read and agreed to the published version of the manuscript.

Funding: This research was funded by the Faculty of Economic and Technical Sciences of the State School of Higher Education in Biała Podlaska, grant number WNET/KEZ/ZE/1.

Conflicts of Interest: The authors declare no conflict of interest.

\section{References}

1. GUS. Rural Areas in Poland in 2018: Statistical Analysis; GUS: Warszawa, Poland, 2020.

2. Czudec, A.; Miś, T.; Zając, D. Zrównoważony Rozwój Obszarów Wiejskich w Wymiarze Regionalnym; Bogucki Wydawnictwo Naukowe: Poznań, Poland, 2018. (In Polish)

3. United Nations. Our Common Future, Report of the World Commission on Environment and Development; Oxford University Press: Oxford, UK, 1987.

4. Shucksmith, M.; Ronningen, K. The uplands after neoliberalism? The role of the small farms in rural sustainability. J. Rural Stud. 2011, 27, 275-287. [CrossRef]

5. Bowler, I.R.; Bryant, C.R.; Coclin, C. (Eds.) The Sustainability of Rural Systems: Geographical Interpretations; Springer Science, Business Media: Berlin, Germany, 2002.

6. Lisocka-Jaegermann, B. Sustainable rural development or sustainable rural livelihoods strategies for 21st century in peripheral regions. Barometr. Reg. Anal. Prog. 2015, 39, 13-20.

7. Scoones, I. Sustainability. In Deconstructing Development Discourse Buzzwords and Fuzzwords; Cornwall, A., Eade, D., Eds.; Practical Action Publishing Ltd.: Rugby, UK, 2010; pp. 153-162.

8. Chambers, R.; Conway, G.R. Sustainable Rural Livelihoods: Practical Concepts for the 21st Centur; IDS Discussion Paper; IDS: Brighton, UK, 1992.

9. Marsden, T. The Conditions of Rural Sustainability; Royal van Gorcum: Assen, The Netherlands, 2003.

10. Borys, T. Aksjologiczne podstawy zrównoważonego i inteligentnego rozwoju. Ekon. Środ. 2016, 3, 33-46. (In Polish)

11. Camarero, L.; Cruz, F.; Oliva, J. Rural sustainability, inter-generational support and mobility. Eur. Urban Reg. Stud. 2014, 23, 734-749. [CrossRef]

12. Bryant, C.; Granjon, D. Rural sustainability. In Human Settlement Development, Encyclopedia of Life Support Systems; EOLSS Publisher: Montreal, QC, Canada, 2009; Volume 2, pp. 158-167. 
13. Adamowicz, M.; Zwolińska-Ligaj, M. New concept for rural development in the strategies and policies of the European Union. Econ. Reg. Stud. 2018, 11, 7-31. [CrossRef]

14. FAO UN. Innovation for Sustainable Rural Development; FAO UN: Santiago, Chile, 2017.

15. OECD. Enhancing rural innovation. In Proceedings of the 11th OECD Rural Development Conference, Edinburgh, UK, 9-12 April 2018.

16. Sobczyk, W. Sustainable development of rural areas. Prob. Sustain. Dev. 2014, 9, 51-62.

17. Transforming Our World: The 2030 Agenda for Sustainable Development. Available online: https: //sustainabledevelopment.un.org/post2015/transformingourworld (accessed on 27 July 2020).

18. Garcia-Feijoo, M.; Eizaguirre, A.; Rica-Aspiunza, A. Systematic review of sustainable-development-goal deployment in business schools. Sustainability 2020, 12, 440. [CrossRef]

19. European Commission. Europa 2020, A Strategy for Smart, Sustainable and Inclusive Growth, Communication from the Commission; European Commission: Brussels, Belgium, 2010.

20. Mihai, F.C.; Iatu, C. Sustainable rural development under Agenda 2030. In Sustainability Assessment at the 21st Century; Bastante-Ceca, M.C., Fuentes-Bargues, J.L., Hufnagel, L., Mihai, F.C., Iatu, C., Eds.; IntechOpen: London, UK, 2020. [CrossRef]

21. Lekić, O.Z.; Gadžić, N.; Milovanović, A. Sustainability of rural areas-Exploring values, challenges and socio-cultural role. In Sustainability and Resilience-Socio-Spatial Perspective; Fikfak, A., Kosanović, S., Konjar, M., Anguillari, E., Eds.; TU Delft Open: Delft, The Netherlands, 2018; pp. 171-184.

22. Bański, J. Wieś w badaniach geograficznych-ewolucja badań i przegląd koncepcji obszarów wiejskich. In Wieś Jako Przedmiot Badań Naukowych na Poczatku XXI Wieku; Halamska, M., Ed.; Wydawnictwo Naukowe Scholar: Warszawa, Poland, 2011; pp. 29-44. (In Polish)

23. Zwolińska-Ligaj, M.A. Ksztattowanie Lokalnych Systemów Innowacji Jako Sposób Realizacji Koncepcji Inteligentnego Rozwoju na Przykładzie Regionów Peryferyjnych; Monografie i Rozprawy nr 9; Wydawnictwo PSW im. Papieża Jana Pawła II: Biała Podlaska, Poland, 2018. (In Polish)

24. Akgun, A.A.; Baycan, T.; Nijkamo, P. Rethinking on sustainable rural development. Eur. Plan. Stud. 2015, 23, 678-692. [CrossRef]

25. Guzal-Dec, D. Intelligent development of the countryside-The concept of smart village: Assumptions, possibilities and implementation limitations. Econ. Reg. Stud. 2018, 11, 32-49. [CrossRef]

26. Dacko, A.; Dacko, M. Studia nad rozwojem obszarów wiejskich-Od paradygmatu wzrostu do rezyliencji. Wieś Roln. 2018, 179, 49-64. (In Polish)

27. Heijman, W.; Hagelaar, G.; van der Heide, M. Rural Resilience as a New Development Concept, No 162359, 100th Seminar, 21-23 June 2007, Novi Sad, Serbia and Montenegro; European Association of Agricultural Economists: Gand, Belgium, 2007.

28. Zavratnik, V.; Kos, A.; Stojmenova Duh, E. Smart villages: Comprehensive review of initiatives and practices. Sustainability 2018, 10, 2559. [CrossRef]

29. Shcherbina, E.; Gorbenkova, E. Smart city technologies for sustainable rural development. IOP Conf. Ser. Mater. Sci. Eng. 2018, 365, 022039. [CrossRef]

30. Wolski, O. Smart Villages in EU Policy: How to Match Innovativeness and Pragmatism? Wieś Roln. 2018, 181, 163-179. (In Polish) [CrossRef]

31. Konecny, O. The Leader approach across the European Union: One method of rural development, many forms of implementation. Eur. Countrys. 2019, 11, 1-16. [CrossRef]

32. Belliggiano, A.; Sturia, A.; Vassallo, M.; Vigano, L. Neo-endogenous rural development in favor of organic farming: Two case studies from Italian fragile areas. Eur. Countrys. 2020, 12, 1-29. [CrossRef]

33. Szczech-Pietkiewicz, E. Smart city_Próba definicji i pomiaru. Prace Nauk. Uni. Ekon. Wroc. 2015, 397, 71-82. (In Polish) [CrossRef]

34. Dudek, M.; Karwat-Woźniak, B.; Wrzochalska, A. Wybrane Determinanty Polaryzacji Społecznej Oraz Stabilności Ekonomicznej na Obszarach Wiejskich; IERiGŻ: Warszawa, Poland, 2016. (In Polish)

35. Adamowicz, M. Smart specialization as a way of strengthening the innovation potential of regions. Acta Sci. Pol. Oeconomia 2016, 15, 5-15.

36. Pilarska, C. Koncepcja Smart Specialisation w polityce ekonomicznej Unii Europejskiej 2014. Stud. Eur. 2014, 4, 59-81. (In Polish)

37. Foray, D.; David, P.A.; Hall, B.H. Smart Specialization: From Academic Idea to Political Instrument, the Surprising Career of a Concept and the Difficulties Involved; MTEI Working Paper; EPFL: Lausanne, Switzerland, 2011. 
38. Kardas, M. Inteligentna specjalizacja-Nowa koncepcja polityki innowacyjnej. Optim. Stud. Ekon. 2011, 50, 124-138.

39. European Commission. EU Action for Smart Villages, 12 April 2017. Available online: http://enrd.ec.europa.eu (accessed on 30 May 2018).

40. Zwolińska-Ligaj, M.; Guzal-Dec, D.; Adamowicz, M. Koncepcja inteligentnego rozwoju lokalnych jednostek terytorialnych na obszarach wiejskich regionu peryferyjnego na przykładzie województwa lubelskiego. Wieś Roln. 2018, 179, 247-280. (In Polish)

41. Wójcik, M. Wprowadzenie. In Inteligentny Rozwój Obszarów Wiejskich (Smart Rural Development): Koncepcja, Wymiary, Metody; Wójcik, M., Ed.; Global Point: Łódź, Poland, 2018; pp. 7-13. (In Polish)

42. Krievina, A.; Leimane, I.; Melece, I. Role of local action group in addressing regional development and social problems in Latvia. Res. Rural Dev. 2015, 2, 146-153.

43. Naldi, L.; Nilsson, P.; Westlund, H.; Wixe, S. What is smart rural development? J. Rural Stud. 2015, 40, 9-101. [CrossRef]

44. Sumter, D.; de Koning, J.; Bakker, C.; Balkenede, R. Circular economy competencies for design. Sustainability 2020, 12, 1561. [CrossRef]

45. Pilot Project: Smart Eco-Social Villages: Final Report; Directorate-General for Agriculture and Rural Development (European Commission), ECORYS, Origin For Sustainability, R.E.D: Brussels, Belgium, April 2019.

46. Pollermann, K.; Raue, P.; Schnaut, G. Rural development experiences in Germany: Opportunities and obstacles in fostering smart places through LEADER. Stud. Agric. Econ. 2013, 115, 111-117. [CrossRef]

47. Guzal-Dec, D.; Zwolińska-Ligaj, M. The role of Local Action Groups in the proces of multifunctional development of peripherial region. A case study of the Lublin Region. Wieś Roln. 2017, 3, 97-120.

48. Nardone, G.; Sisto, R.; Lopolito, A. Social capital in the LEADER initiative: A methodological approach. J. Rural Stud. 2010, 26, 63-72. [CrossRef]

49. Teilmann, K. Measuring social capital accumulation in rural development. J. Rural Stud. 2012, 28, 458-465. [CrossRef]

50. EU. Bled Declaration for a Smarter Future of the Rural Areas in EU. 2018. Available online: http://pametne-vasi. info/wp-content/uploads/2018/04/Bled-declaration-for-a-Smarter-Future-of-the-Rural-Areas-in-EU.pdf (accessed on 1 May 2020).

51. Obrębalski, M. Specjalizacja i inteligentne miasta-Identyfikacja, pomiar ocena. In Specjalizacja RegionalnaWspótczesne Podejścia; Klasik, A., Kuźnik, F., Eds.; Studia KPZK PAN: Warszawa, Poland, 2016; pp. 112-124. (In Polish)

52. Hajduk, S. The concept of smart city in urban management. Bus. Manag. Educ. 2016, 14, 34-49. [CrossRef]

53. Kukuła, K. Regionalne zróżnicowanie stopnia zanieczyszczenia środowiska w Polsce a gospodarka odpadami. Przedsięb. Zarz. 2014, 15, 183-198.

54. StatSoft. Elektroniczny Podręcznik Statystyki PL; StatSoft: Kraków, Poland, 2006.

55. European Commission. Competitiveness in Low-Income and low-Growth Regions; The Lagging Regions Report; Commission Staff Working Document; European Commission: Brussels, Belgium, 2017.

56. Miszczuk, A. Uwarunkowania Peryferyjności Regionu Przygranicznego; Wydawnictwo Norbertinum: Lublin, Poland, 2013. (In Polish)

57. Farole, T.; Rodríguez-Pose, A.; Storper, M. Cohesion policy in the European Union: Growth, geography, institutions. J. Common Mark. Stud. 2011, 49, 1089-1111. [CrossRef]

58. Rodríguez-Pose, A.; Crescenzi, R. Research and development, spillovers, innovation systems, and the genesis of regional growth in Europe. Reg. Stud. 2008, 42, 51-67. [CrossRef]

59. McCann, P.; Ortega-Argilés, R. Modern regional innovation policy. Camb. J. Reg. Econ. Soc. 2013, 6, 187-216. [CrossRef]

60. Isaksen, A.; Karlsen, J. Innovation in peripheral regions. In Handbook on the Geographies of Innovation; Shearmur, R., Carrincazeaux, C., Doloreux, D., Eds.; Edward Elgar Publishing: Cheltenham, UK, 2016; pp. 277-285.

61. Stanny, M. Typologia wiejskich obszarów peryferyjnych pod względem anatomii struktury społeczno-gospodarczej. Wieś Roln. 2011, 2, 59-75. (In Polish)

62. Schürmann, C.; Talaat, A. Towards a European Peripherality Index: Final Report; Report for General Directorate XVI Regional Policy of the European Commission; Institut für Raumplanung, Fakultät Raumplanung, Universität Dortmund: Dortmund, Germany, 2000. 
63. Adamowicz, M.; Zwolińska-Ligaj, M. Koncepcja wielofunkcyjności jako element zrównoważonego rozwoju obszarów wiejskich. Zesz. Nauk. SGGW Wars. 2009, 67, 11-38. (In Polish)

64. Stanny, M. Przestrzenne Zróżnicowanie Rozwoju Obszarów Wiejskich w Polsce; IRWiR PAN: Warszawa, Poland, 2013. (In Polish)

65. Lundwall, B.A. National Systems of Innovation: Towards a Theory of Innovation and Interactive Learning; Anthem Press: London, UK, 2010.

66. Yin, X.; Chen, J.; Li, J. Rural innovation system: Revitalize the countryside for a sustainable development. J. Rural Stud. 2020, in press. [CrossRef]

67. European Commission. Sustainable Development Indicators to Monitor the Implementation of the EU Sustainable Development Strategy; European Commission: Brussels, Belgium, 2005.

68. Dudek, M. Opportunities and barriers for smart rural development in the light of field studies. Econ. Reg. Stud. 2018, 11, 57-68. [CrossRef]

69. Vaishar, A.; Št'astná, M. Smart Village and Sustainability. Southern Moravia Case Study. Eur. Countrys. 2019, 11, 651-660. [CrossRef]

70. Burja, C.; Burja, V. Sustainable development of rural areas: A challenge for Romania. Environ. Eng. J. 2014, 13, 1861-1871. [CrossRef]

71. Komorowski, Ł.; Stanny, M. Smart villages: Where can they happen? Land 2020, 9, 151. [CrossRef]

72. Wilkin, J. Wielofunkcyjność rolnictwa-Nowe ujęcie roli rolnictwa w gospodarce i społeczeństwie. In Wielofunkcyjność Rolnictwa. Kierunki Badań, Podstawy Metodologiczne i Implikacje Praktyczne; Wilkin, J., Ed.; IRWiR PAN: Warszawa, Poland, 2010; pp. 17-40. (In Polish)

73. Ventura, P.; Millone, F.; Berti, G.; Brunoni, B. Some notes on identification of rural webs. In Networking the Rural: The Future of Green Regions in Europe; Milone, P., Ventura, F., Eds.; Van Gorcum: Assen, The Netherlands, 2010; pp. 30-48.

(C) 2020 by the authors. Licensee MDPI, Basel, Switzerland. This article is an open access article distributed under the terms and conditions of the Creative Commons Attribution (CC BY) license (http://creativecommons.org/licenses/by/4.0/). 